\title{
BRICS Koşullu İhtiyat-Fonu Düzenlemesi: Hukuksal ve Kurumsal İnceleme
}

DOI: $10.21492 /$ inuhfd.387923

\begin{abstract}
Mete ERDEM*
ÖZET

1929 Büyük Ekonomik Buhranın yarattığı mali krizin bir daha yaşanmaması için İkinci Dünya Savaşı Sonunda Bretton Woods sistemi bir uluslararası para/finans hukuku rejimi yaratmak üzere kurulmuştur. 1973'de sistemin çökmesine rağmen, uluslararası mali düzen Bretton Woods kurumları IMF ve Dünya Bankasının neoliberal kapitalist makroekonomik politikaları ile şekillenmeye devam etmiştir. Sermaye piyasalarının liberalleşmesi dünya ekonomisinde finansal küreselleşmeye yol açmıştır. BRICS yükselen piyasa ekonomileri ve gelişmekte olan devletlerde ortaya çıkan küresel finans krizlerine bir tepki olarak global ekonomik idarenin değiştirilmesi ihtiyacıyla ortaya çıkmıştır. BRICS Koşullu İhtiyat Fonu Düzenlemesi, Bretton Woods modeline karşı, yeni uluslararası finansal mimarinin yapı taşlarındandır.
\end{abstract}

Anahtar Kelimeler: Bretton Woods, IMF, uluslararası para/finans hukuku, küresel mali kriz, BRICS Koşullu İhtiyat-Fonu Düzenlemesi, yeni uluslararası finansal mimari

\section{BRICS Contingent Reserve Arrangement: A Legal and Institutional Study}

\begin{abstract}
ASBTRACT
The aftermath of the Second World War marked the establishment of the Bretton Woods system as the legal and institutional framework of the international monetary/financial order, swith a view to avoiding the repetation of the Great Depression of 1929. Despite the collapse of the system in 1973, its institutions, IMF and World Bank continued to shape the international financial system by pursuing macroeconomic policies based on neoliberal capitalism. As a result, liberalisation of capital markets led to financial globalisation, thereby causing global financial crises. BRICS has emerged in part as a reaction to the existing global monetary/financial governance and its failure in crisis

\footnotetext{
* Avukat (İst.Baro), LL.B. (Ist), MA (Ist.), LL.M. (Exon), MPhil (Reading), PhD (Sheffield), halen Fulbright visiting scholar Georgetown University Law Center Washington DC. Bu çalışma, TUBİTAK tarafindan sağlanan mali destek ile Max Planck Uluslararası Hukuk Enstitüsü- Heidelberg'de yapılan araştırmalar sırasında Amerikan Uluslararası Hukuk Derneği (ASIL), Avrupa Uluslararası Hukuk Derneği (ESIL) ve Max Planck Uluslararas1 Hukuk Enstitüsü (MPIL) tarafindan 11-12 Aralık 2015 tarihlerinde Heidelberg'te düzenlenen 'BRICS Çağında Transatlantik Ekonomik İdaresinin Geleceği' konulu uluslararası uzmanlar çalıştayına davetli tartışmacı olarak yapılan bir sunumdan geliştirilmiştir. Yazar, İnönü Üniversitesi Genel Sekreteri ve bir zaman Hukuk Müşaviri olan Av. Metin Bulut'a öneri ve düzeltmeleri için teşekkür borçludur.
} 
prevention, management and resolution mostly in emerging market economies and developing countries. The study examines the BRICS Contingent Reserve Arrangement as one of the building blocks of a 'new international financial architecture' as forming against the Bretton Woods model of legal regulation and institutional governance in international financial law.

Keywords: Bretton Woods, IMF, international Money/finance law, global financial crisis, BRICS Contingent Reserve Arrangement, new international financial architecture

\section{Giriş}

2014 tarihinde Brezilya'nın Fortaleza şehrinde toplanan BRICS (Brezilya, Rusya, Hindistan, Çin ve Güney Afrika) devlet başkanları altıncı zirvesi, Yeni Kalkınma Bankası Hakkında bir Anlaşma ile BRICS Koşullu İhtiyat-Fonu Düzenlemesini Kuran bir Andlaşma'yı imzalayarak, birlikteliğin kurumsallaşması yönünde önemli bir somut adım atmıştır ${ }^{1}$. Böylece BRICS içerisinde kurulan ilk uluslararası mali teşkilatın yapılanması, 2015 yılında Rusya'da yapılan yedinci devlet başkanları zirvesinde kabul edilen Ufa Bildirisi ile resmen yürürlüğe girmiştir ${ }^{2}$. Ekonomik bir kriz halinde karşılıklı parasal destek sağlamak amacı güden bu yeni uluslararası finans mekanizması, küresel anlamda mali güvenlik ağının bir parçası olarak düşünülmüştür ${ }^{3}$. Ancak bu oluşumun arkasındaki temel neden, İkinci Dünya Savaşından sonra hukuken uluslararası mali düzenlemeleri yapmak ve yürütmek üzere kurulan Bretton Woods örgütlenmesinin işleyişinden tatmin olmayan gelişmekte olan devletler arasında uzun bir süredir artan memnuniyetsizliğin yol açtığ1 şikayetlerdir ${ }^{4}$. Bu durum aslında uluslararası ekonomi hukukunda ticarete dair çok daha köklü yapısal bir sorunun dışa yansımasıdır ${ }^{5}$. BRICS devletleri bünyesinde ortaya çıkan Yeni Kalkınma Bankası ve Koşullu İhtiyat-Fonu Düzenlemesi şeklindeki örgütsel yapılanma, bu anlamda

\footnotetext{
${ }^{1}$ Bkz. Brazilya Dışişleri Bakanlığg BRICS resmi portalı, http://brics.itamaraty.gov.br; the Agreement on the New Development Bank and the Treaty for the Establishment of a BRICS Contingent Reserve Arrangement, metinler için bkz. http://www.brics.utoronto.ca/docs/

2 Ufa Declaration para.2, VII. BRICS Summit, Ufa, Russia, 9 July 2015, http://en.brics2015.ru/documents/ ; http://www.brics.utoronto.ca/docs/

${ }^{3}$ A.g.e., para.16.

${ }_{5}^{4}$ A.g.e., para. 11 .

${ }^{5}$ Uluslararası ticarette paranın değişimi be ödemeler dengesine ilişkin temel hususlar için bkz. Andreas F. Lowenfeld, International Economic Law (Second Edition, Oxford: Oxford University Press, 2008) 9-19.
} 
mevcut küresel para mübadele ve dolaşımının idaresi bakımından son zamanlarda oldukça tartışılan 'yeni bir uluslararası finansal yapının' ihdas edilmesi ihtiyacı ile doğrudan ilişkilidir' .

$\mathrm{Bu}$ çalışmanın amacı, BRICS Koşullu İhtiyat-Fonu Düzenlemesini hukuksal ve kurumsal açıdan incelemektir. Bu çerçevede, Bretton Woods kurumlarına karşı bir alternatif mahiyetteki bu oluşumun etkisini değerlendirebilmek için, ilk alt başlık altında gelişmiş batılı ekonomiler ekseninde uluslararası para ve finans hukukunun ortaya çıkış1, örgütsel menşei, amaçları ve yapısı tarihsel gelişimi içerisinde kısaca özetlenmiştir. İkinci alt başlık altında ilk olarak, son yıllarda yaşanan bölgesel ve uluslararası ekonomik krizler ile küresel mali istikrarsızlığa neden olan mevcut uluslararası hukuk düzeni içerisindeki yapısal eksiklik ve yetersizliklerin nasıl yeni bir uluslararası finansal yapılanma ihtiyac1 doğurduğu hususu incelenmiştir. Daha sonra bu düzen içerisinde 'uluslararası para' arzının kontrolüne ilişkin temel yapısal sorunların somutlaştırılmasına çalışılmıştır. Üçüncü alt başlık, klasik laissez-faire liberal ideolojinin bu kez neoliberal kapitalizm şeklinde küresel olarak dirilişinin yarattığı finansal krizlere sınırlı anlamda bir tepki olarak ortaya çıan BRICS oluşumu ve mali örgütlenmesi içerisinde Koşullu İhtiyatFonu Düzenlemesini kuran Andlaşmanın içerdiği kurumsal yapıya ve bu yapının işleyişine ilişkin idari hükümlerin incelenmesine ayrılmış̧ır. Son bölümde ise, henüz faaliyete geçen Koşullu İhtiyat-Fonu Düzenlemesinin yeni bir uluslararası finansal düzenin tasarımı içerisinde gelecekteki olası rolü, etkisi ve cazibesi tartışma konusu yapılmıştır.

Çalışma, son yıllarda ortaya çıkan küresel mali krizlerin ve halen devam eden bazı devletlerin kamusal dış borçlanma krizinin (sovereign debt crisis) Uluslararası Para Fonu (IMF) ve Dünya Bankasının işlevi ve amaca uygunluğunu bir kez daha tartışmaya açtığını ve Koşullu İhtiyatFonu Düzenlemesinin yeni uluslararası finansal mimarinin bir yapı taşı olarak bu alanda uluslararası hukukun şekillenmesine sınırlı da olsa katkıda bulunacağını savunmaktadır.

\footnotetext{
${ }^{6}$ Mayamiko Biziwick, Nicolette Cattaneo \& David Fryer, 'The Rationale for and Potential Role of the BRICS Contingent Reserve Arrangement' (2015) 22 South African J. Int'l Affairs 307-8; Yeni bir uluslararası finansal mimarinin gereği için genel olarak bkz. Barry Eichengreen, Toward a New International Financial Architecture: A Practical Post-Asia Agenda (Washington, DC: Institute for International Economics, 1999).
} 


\section{Bretton Woods Sisteminin Kısa Tarihi ve Uluslararası Para ve Finans Düzeni}

İkinci Dünya Savaşından önce devletlerin para ilişkilerini ve buna dair davranışlarını düzenleyen bir uluslararası hukuk rejiminin varlığından söz edebilmek mümkün değildir ${ }^{7}$. O dönemde, artık uygulamada değerini yitirmiş ve yerini klasik ekonomi teorilerine bırakmış olan orta çağın 'adil fiyat' (just price) düşüncesi ile merkantilist anlayışının bazı kalıntıları varlığını sürdürmekteydi. Ancak tarihsel olarak, orta çağın ticari ve endüstriyel ilişkileri ve yapısının çökmesiyle onun yerine geçen merkantilizm, Avrupa ülkelerinde güçlü merkezi ulus-devlet modeli yaratmaya yönelik ekonomik politikaları içeren bir sistem olarak ortaya çıkmıştı ${ }^{8}$. Merkantilizmin onaltı ve onsekizinci yüzyıllar arasında rağbet gören ve pratik öneme sahip bazı ekonomik problemlere bu yaklaşımı, daha sonraki yüzyılda da devletlerin makroekonomik politikalarını etkilemeye devam etmiştir.

\section{Bretton Woods Öncesi Makroekonomik Düzen}

Onyedinci yüzyılda mutlak merkeziyetçi monarşinin zirvesinde Fransa kralı 14. Louis ve danışmanı Mazarin ile onun yerine geçen maliye bakanı Jean-Baptiste Colbert, devletin servetini sahip olduğu altın ve gümüş miktarı ile ölçen bir ekonomik politika izlemeye başlamışlardı ${ }^{9}$. Adam Smith devletin servetini altın ve gümüşten ibaret gören bu görüşü eleştirirken, bunun tek hedefinin ulusal endüstri ve ticaretin en büyük amac1 olarak bu değerli metalleri çoğaltmak olduğunu belirtmiş ve merkantilizmin dayandığ iki ilkeyi şöyle tanımlamıştır:

'kendisinde maden bulunmayan bir ülkeye bu metaller, sadece ya ticaret dengesi ile ya da ithal ettiğinden daha yüksek değerde ihracatta bulunarak getirilebilir; siyasi ekonominin en büyük gayesi ise, ülke tüketimi için yabancı malların ithalatını olabildiğince çok azaltmayı ve yerli endüstri ürünlerinin ihracatını olabildiğince çok arttırmayı gerektirir. $\mathrm{Bu}$ [görüşün] ülkenin zenginleşmesi için iki

\footnotetext{
${ }^{7}$ Lowenfeld (2008), International Economic Law 598.

${ }^{8}$ Takashi Negishi, History of Economic Theory (Amsterdam: Elsevier, 1989) 8-11.

${ }^{9}$ Genel olarak bkz. Glenn J. Ames, Colbert, Mercantilism and the French Quest for the Asian Trade (Illinois: Northern Illinois University Press, 1996).
} 
büyük motoru, ithalat üzerindeki sinırlamalar ile ihracatı teşviktir. ${ }^{10}$

Uluslararası ticarette altını ölçüt kabul eden bir sistemin, ithalat ve ihracatta ödemeler ve kambiyo mekanizmaları üzerinde etkisi de kaçınılmaz olmuştur. Nitekim bu açıdan salt altın standardına dayanan bir sistem, ülkedeki ulusal para biriminin eldeki altın miktarı ile tanımlanmasını ve böylece paranın diğer yabancı paralar karşısında sabit bir kur üzerinden değerlendirilmesini sağlar. Tedavüle kâğıt para sürülen bir ülkede ulusal hazine veya merkez bankası, altın karşılığı ilan ettiği belli bir orana bağlı olarak para basma taahhüdü altına girmiş olur. Böylece tedavüldeki para miktarı, birebir oranda olmasa da, belli bir oranda altın kuruna sabitlenmiş olur. Uluslararası döviz arbitrajı ve ödemeler sistemi bakımından sabit kurun korunmasının bazı avantajları vardır; hem paranın değerinde tahrifatı önler ve hem de bir derece öngörülebilirlik getirir. Altına sabitlenmiş bir kurun teorik olarak kendi içerisinde ekonomide denge sağlayacak bir düzelme mekanizması içerdiğ $i$ varsayılmıştır ${ }^{11}$. Ama gerçek hayatta ekonomik daralma, bunalım, işsizlik ve enflasyonla karşı karşıya kalan bir ülkenin genellikle korumacı tedbirlere başvurarak ihracatını arttırma ve ithalatını azaltmanın yollarını aradığg 1 görülür ${ }^{12}$.

Nitekim bu dönemde ülkeler arasında ikili anlaşmaların dışında ticari ilişkileri düzenleyen veya teşvik eden herhangi bir çok taraflı kapsamlı andlaşma veya uluslararası kuruluş bulunmadığı için, modern anlamda bir dünya ticaret sisteminden söz etmek de mümkün değildi ${ }^{13}$. Birinci Dünya Savaşının çıkmasıyla, Fransa ve Almanya gibi diğer büyük ekonomilerin para birimleri gibi, İngiltere salt altın standardına sabitlenen İngiliz Sterlininin değerini koruyamaması sebebi ile serbest kura geçmiş ve böylece sabit kur sistemi çökmüştür. Sadece kısa bir süre için $\mathrm{ABD}$ hariç, diğer bütün gelişmiş devletler iki Dünya Savaşı arasındaki dönemde hiç bir uluslararası kurala tabi olmadan ulusal çıkarları doğrultusunda

10 Adam Smith, An Inquiry into the Nature and Causes of the Wealth of Nations (Hampshire: Harriman House, 2007) 289.

${ }^{11}$ Bkz Hume'un 'Of the Balance of Trade' in Eugene F. Miller (Ed), David Hume's Essays: Moral, Political and Literary (Liberty Fund, 1987) Part II:V.

${ }^{12}$ Lowenfeld (2008), International Economic Law 10-2.

${ }^{13}$ Mark J. Wolff, 'Failure of the International Monetary Fund \&World Bank to Achieve Integral Development: A Critical Historical Assessment of Bretton Woods Institutions Policies, Structure \& Governance' (2013-2014) 41 Syracuse J. Int'l L. \& Com. 76. 
sınırlarını ithalata kapatmış ve kendi paralarının uluslararası tedavülde dolaşmasına tek taraflı olarak hiç bir denetim mekanizmasına tabi olmadan müdahale etmeye başlamışlardı. Dünya çapında ciddi ekonomik durgunluk ve işsizlik yaşayan devletler, bu darboğazdan çıkabilmek için rekabetçi devalüasyon, çok seviyeli değişken döviz kurları, ticaret sınırlamaları ve sübvansiyonun yanı sıra ekonomik daralmayı dişa yönlendirmek için gerekli gördükleri diğer her türlü korumacı denetim tedbirlerini almaktan çekinmediler.

Böylece uluslararası para sisteminde bir kaos sürecine girildi. Bütün devletleri derinden etkileyen 1929 Büyük Ekonomik Buhranı, bu süreçte İkinci Dünya Savaşının çıkmasındaki en önemli nedenlerden biri olarak görülmüştür ${ }^{14}$. İki Dünya Savaşı arasındaki dönemde devletlerin karşılıklı para ilişkilerindeki tek taraflı belirleyici tutumu, savaş sonrasında sabit döviz kurlarına bağlı çok taraflı bir düzenleyici sistemin lüzumu hakkında en azından galip devletlerarasında bir görüş birliği yaratmıştır.

\section{Bretton Woods Konferansı ve Uluslararası Para/Finans Hukuku Rejimi}

Henüz İkinci Dünya Savaşı bitmeden 1944 yılının Temmuz ayında İngiltere ve ABD ile beraber ${ }^{15}$ bunların müttefiki konumundaki kırkdört devletin temsilcisi, Bretton Woods, New Hampshire'da toplanmış ve uluslararas1 para/finans hukuku rejimi ihdas etmek ve bunun uygulanmasını sağlamak üzere daimi bir uluslararası teşkilat kurmak için çok taraflı bir uluslararası andlaşma imzalamışlardır ${ }^{16}$. Bu ülkelerin paylaştı̆̆1 ortak görüş, iki Dünya Savaşı arasında yaşanan uluslararası ekonomik istikrarsızlı̆̆ın bir kez daha yaşanmaması idi. Bu dönemde eksikliği derin bir şekilde hissedilen bir finansal sistemin kurulması gerekliydi ve bu şekilde uluslararası ödemelerin bir hukuki düzene bağlanması şarttı.

141929 Büyük Buhranın ayrıntı bir incelemesi için bkz. John Arthur Garraty, The Great Depression: an inquiry into the causes, course, and consequences of the worldwide depression of the nineteen-thirties, as seen by contemporaries and in the light of history (New York: Harcourt Brace Jovanovich, 1986).

15 Barışın yanısıra uluslararası mali istikrar ve eşit uluslar arasında serbest ticaret hususunda görüşme ve planlamalar 1942 yılında İngiltere ve ABD arasında başlamıştır.

${ }^{16}$ Bretton Woods Andlaşmasının siyasi menşei için bkz. G. John Ikenberry, 'The Political Origins of Bretton Woods' in Michael D. Burdo \& Berry Eichengreen (Eds), A Retrospective on the Bretton Woods System: Lessons for International Monetary Reform (Chicago: University of Chicago, 1993) 155. 
Ancak böyle bir sistem sayesinde Büyük Buhran sırasında dünya ekonomisini felç eden ulusal paraların ani değer kaybı veya döviz mübadele kurlarındaki aşırı dalgalanmalar riski asgariye indirilebilirdi. Ekonomik gelişme için ulusal ekonomilerin bütünleşerek uluslararası ticaretin serbest bir şekilde yapılmasının sağlanması gerekiyordu. Bu yeni hukuk rejimi, ayırım gözetmeme ve sabit para mübadelesi kuru gibi ekonomik ilkelerle, söz konusu değişim mekanizması üzerindeki hükümet kontrollerinden ve aynı zamanda mal, hizmet ve kredi akışını tahrif edecek her türlü müdahale ve tedbirlerden kaçınmayı öngören çok taraflı açık (liberal) bir uluslararası ticaret sistemini içermek üzere tasarlanmışt1 ${ }^{17}$.

$\mathrm{Bu}$ genel ilkeler etrafında kurulacak sistemin üç unsuru içermesi öngörülmüştü: ilk olarak, sistem birbiriyle bağlantılı uluslararası sözleşmeler ve örgütler düzenine dayanan resmi ve kurumsal bir yapıya sahip olacaktı. İkinci olarak, ulusal finans piyasaları sınırlı sermaye akışıyla 'kapalı' piyasalar görünümünü korumasına karşılık, malların ticareti bakımından açık hale gelecekti. Üçüncü olarak ise, kapalı ulusal sistemler arasındaki ilişkiler bir uluslararası örgütsel çerçeve etrafinda düzenlenecekti ${ }^{18}$. Bretton Woods Konferans1 bu çerçeve içerisinde uluslararası para sistemini düzenleyen temel hukuk kurallarını, usulleri ve kurumlarını ihdas eden bir yapıyı hayata geçirmiş oldu.

Birinci Dünya Savaşından önce kullanılan salt altın ölçütüne uygulamada geri dönebilmenin imkânsızlığı anlaşıldıktan sonra, devletler en azından buna paralel bir sistem içerisinde kağıt parayı tek başına esas almaktan ziyade ulusal paraların altına sabitlenmiş olarak tedavülde dolaşmasına dayanan bir sistemi benimsemeyi uygun görmüşlerdir.

Bretton Woods sistemi olarak anilan bu uluslararas1 para/finans düzeninin dört temel yap1 taşı üzerine kurulduğu görülmektedir: i.) Amerikan Dolarına Bă̆ll Ayarlanabilir Bir Kambiyo Rejimi: Her üye devlet kendi ulusal para sisteminin altın rezervlerine göre paritesini

\footnotetext{
${ }^{17}$ Ayrıntılı bir inceleme için bkz. Michael D. Bordo, 'The Bretton Woods International Monetary System: A Historical Overview' in Michael D. Burdo \& Berry Eichengreen (Eds), A Retrospective on the Bretton Woods System: Lessons for International Monetary Reform (Chicago: University of Chicago, 1993) 28-37.

${ }^{18}$ Douglas W. Arner (2008), 'The Developing Discipline of International Financial Law', in Colin B. Picker, Isabella D. Bunn and Douglas W. Arner (eds), International Economic Law: The State and Future of the Discipline (Oxford: Hart), 246.
} 
belirleyecek ve parasının döviz çapraz kurlarını uluslararası döviz piyasalarına müdahale ederek bu paritenin $\% 1$ altında veya üstünde kalacak şekilde koruyacaktır. Bu bakımdan ABD doları tek döviz rezerv birimi kabul edilmiş ve dolara güvenin sürdürülebilmesi için $\mathrm{ABD}$ ayrıca doları altına bağlamıştır. Böylece Amerikan dolarının değeri, her bir onsa (28.3 gr) oranla $\$ 35$ olarak tespit edilmiştir. ii.) Üye Devletlerin Para Birimlerinin Değiştirilebilmesini Garanti Eden Bir Sistem: Üye devletler cari hesapları için para birimlerinin dövize çevrilebilirliğini sağlamak zorundadırlar. Ayırım gözeten kambiyo uygulamaları ve para değiştirilmesine ilişkin düzenlemeler getirmek ve varsa bunları muhafaza etmek yeni rejim altında yasaklanmıştır. iii.) Para Rezervlerinin Yeterli Arzını Temin Eden Bir Sistem: İhdas edilen kurumsal yap1 ile üye devletlerin ihtiyaç halinde kısa veya orta vadeli ödemeler dengesindeki açığı finanse edebilmelerine imkan verecek kaynakları kullanabilmeleri için tahsis edilmiştir. Üyelerin kotalarından oluşan fon, ödemeler dengesinde açık veren ülkelerin tedavülde bulunan para miktarındaki daralmayı sınırlamak amacıyla oluşturulan para rezervidir ve kullanımına belli şartlar altında izin verilecektir. iv.) Para Meselelerinde Uluslararası İsbirliği İçin Bir Forum: Bretton Woods sisteminin getirdiği kurumsal yapılanma üye devletlerin atadığı temsilcileri dolayısı ile ilgili para düzenlemeleri hakkında söz sahibi olmasına imkan verir. Böylece önemli uluslararası mali sonuçları olan siyasal kararları almak üzere işbirliği içerisine girebilecekleri bir forum yaratılmış olur. Ancak karar alma usul ve nisab1 her üye devletin ekonomik gücüne sabitlenen bir kotaya bağlandığ için, sistem çok sert eleştirilere maruz kalmıştır. ${ }^{19}$

$\mathrm{Bu}$ şekilde öngörülen istikrarlı döviz mübadele kurları sistemi aslında finans, yatırım ve ticaret alanlarında istikrarı sağlamak düşüncesindeydi. Bunun gerçekleşmesi için ise üçlü bir örgütlenme yapısı tasarlanmıştır. Sermaye dolaşımı ulusal ekonomiler tarafından sınırlanacağı için, Uluslararası Para Fonu (IMF) sermayenin dolaşımını izlemek ve gerektiğinde düzenli değişim ayarlamalarını sağlamak üzere kurulmuştur. Örgütlenmenin ikinci ayağı olan Dünya Bankası (Uluslararası Yeniden Yapılanma ve Kalkınma Bankası) ise kısaca savaş sonrası yeniden inşa edilecek uluslararası ekonominin gerçekleşmesi için finansal yatırımları sağlamak amacıyla kurulmuştur. Bu çerçevede

19 Junji Nakagawa, 'Reconstructing Global Monetary/Financial Governance Beyond Bretton Woods System' (2010) 53 Japanese YIL 103-5. 
uluslararası ticari bağlantıların yeniden kurulabilmesi için, ticari anlaşmaların idaresi ve ticari engellerin ortadan kaldırılmasını sağlayacak bir Uluslararası Ticaret Örgütünün kurulması üzerinde uzlaşılmıştır. ${ }^{20}$

\section{Uygulamada Karşılaşılan Güçlükler}

Bretton Woods uluslararası ekonomik sisteminin öngörüldüğü şekilde uygulamada ortaya çıkmadığı bir gerçektir. Savaş sonrası uluslararası ticaret bağlantıları, Uluslararası Ticaret Örgütünün (UTÖ) önderliğinde uluslararası ticaretin önündeki engellerin azaltılması ve ticareti sınırlayıcı anlaşmaların bir denetime tabi tutulmasıyla yeniden kurulacaktı. Ancak ABD ve Fransa'nın bazı siyasi çekinceleri yüzünden UTÖ başarısızlığa uğradı ve ticari ilişkilerin karşılıklı görüşmeler sürecine dayanan bir sistem içerisinde düzenlenmesi kabul edildi. Hemen ortaya çıkan bir ikinci güçlük ise Dünya Bankasının savaş sonrası yeniden yapılanmayı sağlama görevinin ABD tarafından uygulamaya konulan Marshall Planı gibi ikili ilişkilere dayanan tek taraflı çabalar ile fiilen atıl hale gelmesiydi. Bunlara rağmen, sabit değişim kurlarına dayanan uluslararası para sistemi IMF ekseninde nispeten başarı ile kuruldu ve bu sistem, ABD'nin tek taraflı olarak dolar ile altın arasındaki sabit kur bağlantısını bozduğu 1973 yılına kadar devam etti.

Savaş sonrasındaki ilk dönemde IMF'nin uluslararası mali sistemin oluşturulmasındaki temel rolü, daha çok gelişmiş ekonomiler ile kur oranlarını ayarlamak arasında bir işlev görmeye odaklanmıştır. Bunun bir temel nedeni, ABD dışındaki üye devletlerin mübadele oranları üzerinde etkin kontrol icra etmeyi sürdürmesidir Ayrıca bu devletler ticari ortakları ile aralarında ikili ödeme anlaşmaları yapmaya devam etmişlerdir. Uluslararası döviz rezervlerinin daralması, bu durumu haklı kılmaktaydı. Avrupa'daki altın ve dolar rezervlerinin tükenmeye başlaması ile pek çok ülke ciddi oranlarda cari hesap açı̆̆ı sorunu ile karşılaştı. Bu tipik durum, savaş yorgunu ülkelerde temel ithal ürünlerine olan ani talep artışı karşısında azalan ihracat kapasitesinin bir ifadesiydi. Böylece IMF'nin karşılaştığı iki ciddi problemden bir tanesi piyasada Amerikan doları sıkıntısı yaşanması ve diğeri, kur denetiminin tek taraflı olarak yapılması

20 Bartham Brown, 'IMF Governance, the Asian Financial Crisis, and the New International Financial Architecture' in Sienho Yee \& Wang Tieya (Eds.), International Law in the Post-Cold War World: Essays in Memory of Li Haopei (London: Routledge, 2003) 132-4. 
idi. ${ }^{21}$ Enflasyon ve cari hesap açı̆̆ına çözüm 1958 yılının sonunda alınan bir dizi tedbirler sayesinde geldi. ABD'nin Marshall Planı ve yeni kurulan Avrupa Ödemeler Birliği ile ABD tarafından yapılan nakit para yardımı ve cari hesap transferleri için döviz değişimi rejiminin başarıyla uygulanması çözümler üretti. Ulusal paraların dövize tam çevrilebilirliği, çapraz kurda doların zamanla Sterlin karşısında uluslararası para piyasasının tek müdahale ve dengeleme birimi olarak rolünü arttırdı. Bu şekilde ABD dolarının uluslararası rezervlerin tek kaynağı olarak kullanılmasına imkân sağladı.

Böylece 1970'lere doğru uluslararası sermaye akışı tamamen Amerikan doları üzerinden yapılmaya başladı. 1967 yılına kadar altın ve dolar standardına sabitlenmiş para değişim oranları döviz paritelerine istikrarı getirdi. Ancak bu durum ABD'nin ödemeler dengesindeki açığın zamanla artması sonucu, üç problemi beraberinde getirdi: a) borçlu devletlerin kendi ödemeler dengesinde gereken ayarlamaları yapabilme kabiliyetini kaybetmesi; b) üretim ve ticaretteki artışı finans edecek altın/dolar arzının yeterli olmaması; ve c) altın karşısında sabit dolar oranına olan güvenin kaybolmaya başlaması. 1960'lardan başlayarak, IMF bünyesinde bu duruma öncelikle kendisine ayırılan kaynaklarda artış ile daha sonra da altın standardına bağlanan yeni yapay bir para biriminin yaratılması yoluyla çözüm arandı. Nitekim bu son yöntem ile 1968 yılında özel çekme haklarının (special drawing rights SDR) kullanıma açık bir ek kaynak olarak uluslararası para rezervine katılmasını sağlandı.

Ancak 1971 Ağustos ayında ABD'nin, yabancıların elindeki dolar rezervlerinin altın karşılığını garanti etmekten kaçınması ve doların diğer para birimlerine otomatik çevrilebilirliğini durdurması üzerine, altın standardı sistemi çökmüş oldu. Yüksek enflasyon ve Amerikan dolarının değer kaybına uğramaya başlamasıyla, 1973 Mart ayında dövizde serbest piyasa kuruna geçildi. Bu gelişmeler IMF'nin uluslararası mali sistem içerisindeki para değişim oranlarını düzenleme rolünü etkilemiştir. Böylece IMF Andlaşma hükümlerinde yapılan değişikliklerle, dönemsel para mübadele krizleri yaşayan ekonomilere belli koşullarla borç sağlamak temel faaliyet odağ 1 haline gelmiştir. Oysa IMF'nin başlangıçtaki amacı, cari hesap açığı bir kaç sene gibi kısa dönem içerisinde düzeltilebilecek olan ekonomilerin finansmanına yardım

\footnotetext{
${ }^{21}$ Nakagawa (2010), ‘Reconstructing' 105.
} 
etmekti. 1990'l1 y1llara gelindiğinde ise, IMF'nin gelişmekte olan ekonomilere borç verme politikalarını şartlılık ilkesine bağlayarak, sermaye akışını serbestleştirmek ve ulusal piyasaların açılmasını teşvik etmek amacını benimsediği görülür.

\section{Uluslararası Para/Finans Sisteminin Yapısal Sorunları}

En yalın ifadesi ile mevcut sistemde devletlerin sahip olduğu 'uluslararası para' iki kaynaktan gelebilir. Birinci olarak, üye devletlerin IMF nezdinde sahip oldukları 'kotalar'dır. İkincisi ise kendi hazinelerinde bulunan döviz rezervleridir ki bu çevrilebilir dövizler çoğunlukla ABD dolarıdır. Bir devlet için, meğerki IMF'deki kotalarda bir artış söz konusu olmasın, prensip itibarıyla kendi döviz rezervlerini arttırabilmesinin tek yolu aslında ödemeler dengesinde pozitife geçmesi yani fazla vermesi halidir. Bir başka ifade ile siyahta olmasıdır. Eğer bu fazla miktar ABD doları üzerinden ise o zaman doğal olarak dünya piyasasında Amerikan dolarının arzında bir artış ortaya çıkmış olacaktır. Ama eğer bu fazla başka ülkelerin para birimleri bakımından ortaya çıkmış ise o halde mevcut para arzı sadece yeniden tahsis edilmiş olur ${ }^{22}$. Bu denklemin pratik sonucu olarak, bütün dünyadaki para piyasasında dolar arzının artması, ABD dışındaki devletlerin bir bütün olarak cari hesaplarında fazla vermelerine bağlıdır; yani ABD'nin cari hesap açı̆̆ı vermesi gerekir. Doların tedavüldeki miktarını ABD belirlediğine göre, bu durum iki olasılıkta da ABD'in mali politikalarına bağlı olacaktır.

Bunun dışındaki bir diğer uluslararası para kaynağı olan IMF kotaları bakımından, 'Andlaşma Maddeleri' üye ülkelerin kota tahsislerini beş yılda bir dönemsel olarak gözden geçirileceğini öngörür. Kota artışları yeni üyelerin katlımı ile olabileceği gibi, bazı üyeler bakımından özel olarak anlaşma ile de olabilir. Anlaşma yolu ile kota artışı nitelikli oy çoğunluğuna tabidir. Karar nisab1 \%85 oy çoğunluğunu gerektirir. Örneğin 2008 tarihli reform paketi en az 111 devletin onayını gerektirmiştir. ABD'nin ağırlıklı oy hakk1 \%17 oranında olduğu için fiilen veto hakkına sahiptir ${ }^{23}$. Eğer kotalarda bir artış sağlanamaz ise, bunun bir sonucu olarak ülkelerin ticareti arttıkça ortaya çıkan para ihtiyacını ancak kendi dolar rezervlerini arttırmak suretiyle karşılamak zorunda

\footnotetext{
${ }^{22}$ Manmohan Agarwal, 'The Contingent Reserve Arrangement and the International Monetary System' (2014) 19 Analysis 1.

${ }^{23}$ Sarah Tenney and Norman K. Humphreys, Historical Dictionary of the International Monetary Fund (Third edn, Lanham: Scarecrow, 2011) 251-3.
} 
kalacaklardır. Bunun pratik anlamı, devletlerin dolar satın alarak aslında ABD'ye düşük faiz ile borç temin etmesidir. Bu açıdan, IMF kotalarının artmaması ABD lehine bir durum yaratmaktadır. ABD'nin IMF kotaları üzerindeki bu kontrolü mevcut finans sistemi içerisinde 'uluslararası para' arzını diğer bütün devletlerin kontrolünün dışına çekmektedir. 2008 tarihli reform paketinin ABD Kongresinde reddedilmesinin yarattığı çıkmaz budur $^{24}$.

Ödemeler dengesinde verilen açığın finans edilmesi bakımından ise iki durum söz konusu olabilir. İlk durum özel finansmandır. Bu halde ödemeler dengesinde açık veren bir devlet, bu açığı kapatmak için özel sermaye piyasalarından borçlanmaya yönelir. En yaygın şekli ile devlet ya tahvillerini satış için özel sermayeye arz eder ya da özel ticari bankalardan borç alır. Bu tarzda normal hesap açıklarının kapatılması için özel finansman sağlanması günümüzde çoğu devletlerin başvurduğu bir modern finans yöntemi haline gelmiştir. Ancak mali krizle karşılaşan bir ülke bazen bu özel finansman kaynaklarının da daraldığını görmektedir. Bu durumda, özel finansmanın eksikliği başlı başına krize neden olabilir. Her halükarda özel finansman yolları tükenen bir devlet, çareyi resmi yollardan kredi aramakta bulur. Çoğu kez IMF'den borç almak tek seçenek haline gelebilir ${ }^{25}$. IMF'den mali yardım talep eden bir devletin ihtiyaç duyduğu borç miktarı, IMF'in kendisine tanıdığı borçlanma haklarının çok üzerinde olabilir. Kendisine tahsis edilen kotaların üzerindeki ihtiyaçlar için hususi tahsisatın yapılması gerektirir. Hususi finansman tahsisat1 ihtiyari olduğu için, özel nitelikteki hükümlere tabi kılınır. Bu hükümler hem ekonomik hem de siyasi bazı koşulları içerir. Nitekim IMF'nin geçmişteki şaibeli uygulamaları borç alma koşullarını oldukça sert kriterlere bağlamıştır ve çoğu kez bu koşulların söz konusu edildiği meselelerin aslında krizin kendisi ile doğrudan hiç bir ilgisi olmayan belli bir siyasi gündemin dayatması olarak yapılmıştır ${ }^{26}$. Örneğin, 1997-1998 Güney Doğu Asya ekonomik krizinin arkasındaki temel neden, özel sektörün aşırı borç altına girmesiydi. Ancak tuhaf bir

\footnotetext{
${ }^{24}$ Bkz. aşă̆ı da not. 124.

${ }^{25}$ Agarwal (2014), 'The Contingent Reserve Arrangement' 2.

${ }^{26}$ IMF'nin şartlılık politikaları için bkz. Ilias Bantekas, 'New Challenges and Issues in International Finance Law' in Yusuf Aksar (ed.), Implementing International Economic Law: Through Dispute Settlement Mechanisms (Leiden: Martinus Nijhoff, 2011) 62-3.
} 
şekilde IMF bu ülkelere verdiği krediyi özelleştirme şartına bağlamıştır ${ }^{27}$. Yine yakın geçmişte IMF kredilerinin, özel sektör tarafından yapılan aşırı borçlanmanın yarattığı ekonomik krizlerde kamu sektörü ve maliyesine getirilen sinırlamalar ve koşulları öngörmesi ahlaki bir tehlike olarak eleştirilmiştir.

IMF'nin neoliberal kapitalizme dayanan şartlılık politikaları ve güvence tedbirleri, devletler arasında IMF'e karşı güven bunalımı ve isteksizlik yaratmıştır. Çoğu devlet, IMF kredisi yerine bir ön tedbir olarak kendi döviz rezervlerini oluşturmaya başlamıştır. Ancak bu yaklaşımda uluslararası para sisteminin işleyişinde farklı nitelikte ek bir sorun yaratmaktadır. Şöyle ki, nispeten fakir devletlerin para rezervlerini biriktirme eğilimi içerisine girmeleri uygulamada dolayısıyla bu devletler tarafından aslında kendilerinden çok daha fazla zengin olan ABD'ye borç vermesi anlamına gelir. Bu da ekonomik olarak para kaynaklarının yanlış tahsisi sorununu yaratır ${ }^{28}$. Doğal olarak böyle bir durum, kendi lehine olduğu için, ABD'ni mevcut sistemi değiştirmemek hususunda teşvik etmektedir.

Agarwal, yukarıdaki her bir durumun kendi içerisinde barındırdığ 1 güçlüklere işaret ederek, devletlerin ödemeler dengesindeki açı̆̆ını finanse edebileceği miktarın aslında sınırlı olduğunu ifade eder ${ }^{29}$. Nitekim bunu fark eden devletler, cari açığı finanse edilebilir bir seviyede tutabilmek amacıyla, kendilerini harcamaları kısmak ve hesaplarını denkleştirmek için ciddi bir baskının altında hissetmeye başlamışlardır. Oysa benzeri bir baskı, cari hesap fazlası olan devletler bakımından söz konusu değildir. Cari hesabı siyahta olan bir devletin artık rezervlerini birikmesini sinırlayacak tek faktör, para rezervlerinin artmasının yol açacağı yüksek para arzıdır. Talebi aşan para arzı, ilke olarak enflasyonun artması riskini taşır. Ama cari hesap fazlası olan bir devlet enflasyonu kontrol eden önlemleri aldığ sürece, kendisini ödemeler dengesini korumak hususunda herhangi bir zorunluluk ve bask1 altında hissetmeyecektir. Bu bakımdan, ABD ile diğer devletlerarasında asimetrik bir ilişki vardır. Şöyle ki, eğer diğer devletler ödemeler dengesinde açık

\footnotetext{
27 Ayrıntılı bir inceleme için bkz. Eva Reisenhuber, The International Monetary Fund under Constraint: Legitimacy of its Crises Management (The Hague: Kluwer Law Int'1, 2001) 75-131.

${ }^{28}$ Agarwal (2014), 'The Contingent Reserve Arrangement' 2.

${ }^{29} I d$.
} 
vermeye başlarsa, bunu bir yolla kapatmaları gerekir; yoksa kendilerini mevcut para rezervlerini tüketme tehlikesi içerisinde bulurlar. Öte yandan, eğer ABD cari açık verirse, herhangi bir denkleştirici tedbir almasına gerek yoktur, çünkü Amerikan doları 'uluslararası para' olduğu için zaten diğer devletler, ABD'nin arza sunmak üzere bastı̆̆ 1 doları ellerinde tutmaya isteklidirler. Bütün bunların ötesinde, Bretton Woods para sistemi içerisinde özellikle cari hesaplarında ödemeler dengesi açık veren devletler için bu tür denkleştirici tedbirleri alabilmek imkânları finansal küreselleşme yüzünden karmaşık bir görünüm kazanmıştır.

\section{Neoliberalizm, Finansal Küreselleşme ve Küresel Krizler}

Bretton Woods kurumsallaşması, İngiliz ekonomist Keynes'in tam istihdam ve ekonomik istikrar amaçlı eski emperyalist imtiyaz sistemi ve iki taraflı ticari ilişkiler esası yerine Amerikan diplomat White'ın açık, ayırım gözetmeyen ve çok taraflı ticaret sistemine dayanan ekonomik politikalar etrafinda şekillenmiştir ${ }^{30}$. Ancak ilk yıllarda IMF ve Dünya Bankasının ekonomi politikalarının, Keynes'in ekonomik teorileri ve sosyal refah düşüncesinden etkilendiği görülmüştür ${ }^{31}$. Keynes, bir anlamda ekonomilerin kötüye gitmesinin nedenini piyasada toplam talebin yeterince yaratılmamasına bağlar. Üretim fazlasına karşı gereken talebin oluşturulmasına cari para politikalarının etkili olmadığı hallerde, hükümetler kendi alacağı mali tedbirlere dayanarak ya kamu harcamalarını arttırmak ya da vergileri düşürmek suretiyle işsizliğin önüne geçebilir ve ekonomiye istikrar getirebilir. Bunun arkasındaki temel düşünce, piyasa güçlerinin kendi başına bir düzeltme mekanizması bulunmadığ 1 varsayımıdır ${ }^{32}$.

Ancak 1980'lerin ortasından itibaren IMF ve Dünya Bankasının ekonomik politikaları üzerinde Chicago Okulunun 'serbest piyasada tam rekabete dayanan ekonomik etkinlik' görüşünün hakim olmaya başladığ görülmüştür. ${ }^{33} \mathrm{Bu}$ durum, IMF, Dünya Bankası ve ABD Hazine'si arasında 'Washington Consensus' olarak adlandırılan ve gelişmekte olan ülkelere uygulanacak olan sözde "doğru" politikalar üzerinde bir

\footnotetext{
${ }^{30}$ Ikenberry (1993), 'The Political Origins of Bretton Woods' 155-6.

${ }^{31}$ Id., 157.

32 Joseph E. Stiglitz, Globalization and Its Discontents (New York: WW Norton, 2002) 11 ve 196-7.

${ }^{33}$ Wolff (2013-14), 'Failure of the International Monetary Fund' 94.
} 
uzlaşmanın yansımasıdır ${ }^{34}$. Washington uzlaşması, üç iktisadi politika ayağı üzerine kurulmuştur: kamu maliyesinde kemer sıkma, kamu işletmelerinin özelleştirilmesi ve serbest piyasa ekonomisi.

Özellikle bütçesinde büyük açık veren hükümetlerin, iç piyasada rekabeti kısitlayıcı tek taraflı ulusal tedbirler alarak verimsiz ve savurgan kamu iktisadi teşekkülleri ile atıl ve düşük performanslı özel sektörü korumaya çalışması, piyasaların daralmasına ve fiyatların artmasına neden olmaktaydı. Bu durum karşısında hükümetlerin dayandığı yegâne araç olan kamu maliyesinin disiplin altına alması gerekliydi. Böylece devletin kamusal alanının ticari faaliyetlerin dişına çıkartılması ve sadece temel hizmetlerle sınırlı tutulması, hem piyasanın açılmasını sağlayacak ve hem de özel sektöre rekabet gücü kazandıracaktı. Bunun için kamu iktisadi teşekküllerinin özelleştirilmesi öngörülmüştü. Ulusal piyasaların ithalatta gümrük vergi ve tarifelerinin indirilmesi ve kota uygulaması gibi her türlü diğer ulusal korumacı engellerin kaldırılması ve ticaretin serbestleşmesi, tam rekabeti sağlayarak özel sektörü verimli hale getireceği için sonuçta fiyatların düşmesine sebep olacaktı ${ }^{35}$. Bu koşulları yerine getirmeyen ülkelerin, bir yandan ekonomide sürekli açı vermesi, diğer yandan ise yüksek enflasyon yüzünden zaten kalıcı bir büyümeyi yakalayabilmeleri mümkün olamazd. $\mathrm{Bu}$ iddialar ekonomist Milton Friedman'in monetarizm $^{36}$ ve hukukçu Richard Posner'in tam rekabet ${ }^{37}$ tezleri ile derinlemesine tartışılmış ve mensubu oldukları Chicago okulunun ekonomik verimliliği serbest rekabet piyasasına dayandıran neoliberal ekonomik politikaları Washington uzlaşmasının esasını teşkil etmiştir. $\mathrm{Bu}$ tezlerin uygulamas1, hukuki düzenlemelerde serbestlik (deregulation), kamu işletmelerinin özelleştirilmesi ve kamu harcamalarının kısılmasını gerektirmekteydi. Yani bu iddiaya göre, kamu idaresinin dişında kalan bütün ekonomik faaliyetler bakımından en uygun olan sistem, hukuk

${ }^{34}$ Naomi Klein, The Shock Doctrine: The Rise of Disaster Capitalism (New York: Metropolitan, 2007) 163-5.

${ }^{35}$ Stiglitz (2002), Globalization 53, Stiglitz bu politikaların daha sonra nasıl başarısız olduğunu az gelişmiş ve gelişmekte olan devletler bakımından uygulamadaki vahim etkilerini ayrıntılı biçimde ortaya koyar. 54 et seq.

${ }^{36}$ Genel olarak bkz. Milton Friedman, Capitalism and Freedom (Chicago: Chicago University Press, 2002).

${ }^{37}$ Genel olarak bkz. Richard A. Posner, Economic Analysis of Law (New York: Aspen, 2011). 
kuralları yerine sadece kendi içerisinde gönüllü denetime tabi düzenleme ile yürütüleni olmalıydr ${ }^{38}$.

Wolff, genel refahı arttırmak için hükümetleri devletin bütün malvarlığı ve sermayesini özel sektöre satarak, kamu harcamalarını kesmeye, vergileri asgariye indirmeye ve ticaret üzerindeki hukuki düzenlemeleri kaldırmayı öngören bu tür koşulların borç ihtiyacı içerisinde bulunan gelişmekte olan devletlere zorla dayattırılması için, $\mathrm{ABD}$ ve İngiltere gibi batılı gelişmiş endüstriyel devletlerin IMF ve Dünya Bankasını bir araç olarak kullandığını ve böylece kapitalist serbest piyasa ekonomisini küresel olarak bütün dünyaya yaymaya çalıştığını ifade etmektedir ${ }^{39}$. Nitekim IMF ekonomik kriz içerisinde borç isteyen devletleri kurtarma yardımlarını, yapısal değişiklik programlarına eklenen özelleştirme ve ticaretin serbestleştirilmesi koşullarına bağlı olarak yapmıştır. Buna karşılık borcun tabi olduğu faiz oranları IMF tarafindan uluslararası serbest piyasalardaki dalgalanmalara bırakıldığı için, bu şartları yerine getirmeye çalışan devletler çoğu kez ana borcun çok üzerinde bir faiz yükünün altında geri ödemeleri yapamaz hale gelmişlerdir $^{40}$.

1980 ve 1990'lı yıllarda IMF ve Dünya Bankasının yapısal değişim içeren ekonomik politikaları çerçevesinde borç vermede takip ettikleri usul, bir şok tedavisi ile finansal kriz durumunda olan ülkeleri serbest piyasa yaratmaya yönelik bir dizi ekonomik reformlar yapmaya itmiştir. $\mathrm{Bu}$ neoliberal reformlar sonucu sermaye hesabının serbestleştirilmesi ile yükselen piyasa ekonomilerine gelişmiş ülkelerden görülmemiş ölçüde doğrudan yabancı yatırım ve portföy akımına neden olmuştur. Bu durum daha çok ülkenin uluslararası mali sistem içerisinde bütünleşmesine neden olmuştur $^{41}$. Bir örnek olarak Carmody, Afrika'da bu değer yargılarındaki metalaşmanın yayılması ve derinleşmesinin toplumda sosyoekonomik ilişkileri etkilediğini ve bireysel ilişkilerin zamanla piyasalardaki alışveriş ve kar amaciyla şekillenmesine neden olan bir homojenleşme

\footnotetext{
${ }^{38}$ Friedman (2002), Capitalism 65-71.

${ }^{39}$ Wolff (2013-14), 'Failure of the International Economic Fund' 94-5.

40 Latin Amerika devletlerine verilen borçların yarattığı ekonomik yıkımın toplum üzerindeki etkileri için bkz. Klein (2007), The Shock Doctrine 142 et seq.

${ }^{41}$ Sermaye hesabı üzerindeki denetimlerin kaldırılmasına ilişkin ayrıntılı bir açıklama için bkz. Kavaljit Singh, Taming Global Financial Flows: Challenges and Alternatives in the Era of Financial Globalization : A Citizens Guide (New York: Zed, 2000) 57 et seq.
} 
sürecini başlattığını gözlemlemiştir. Ona göre, küreselleşme böyle bir homojenleşme sürecini ifade $\operatorname{eder}^{42}$. Bu anlamda küreselleşme değişik yerler arasında bir benzeşme bağlantısını gösterir. Dünyadaki ülkelerin ve halklarının bütünleşmesini (entegrasyonu) ifade eder. Bütün dünya düzeyinde bu bağlantı ilişkisi, ticaretin, yatırımın, ekonomik yardımların, teknolojinin, insanların, değişik fikir ve görüşlerin ve hatta demokratikleşme gibi siyasi süreçlerin akışına dayanarak homojenleştiği ölçüde küreselleşir. Ekonomik olarak, iletişim ve ulaşım masraflarında sağlanan tasarruf ticaretin maliyetini etkiler. Çünkü malların, hizmetlerin, sermayenin, bilginin, -ve daha az bir seviyede ise- insanların değişik coğrafyalar arasındaki akışının önündeki yapay engellerin kaldırılması ticaretin serbestleşmesine ve ulusal piyasaların rekabete açılmasına neden olur $^{43}$.

Böylece küreselleşmenin merkezinde uluslararası ekonomik düzen vardır ve bu düzen içerisinde devletlerarasındaki ilişkilerin egemen bağımsızlıktan karşılıklı bağımlılı̆ga doğru geliştiği uluslararası ekonomi hukuku bulunur. Ancak ortaya çıkan bu yeni ekonomik düzende finansal küreselleşmenin hukuki boyutu, mevcut uluslararası hukuk sisteminin normatif ve kurumsal yapısı üzerinde salt uluslararası aşmanın çok ötesinde klasik hukukun dışında yeni bir takım sorunları içerir. Nitekim Hobe, küreselleşmenin uluslararası hukuk alanında 'egemen eşit devlet' kavramı bakımından üç yeni unsurun düşünülmesini gerekli kıldığını öne sürer: a) uluslararası hukuku yapılması ve belirlenmesinde devletin yanında siyasi güç kazanan ulus-ötesi (transnational) aktörler, b) devletin tek taraflı ve hükümetlerarası düzenlemelerinin ötesinde hukuki çözümler, ve c) sosyoekonomik, siyasi ve kültürel bütünleşmenin küresel boyutunun neden olduğu egemen devlet eksenli iç ve dış hukuk düzeninde gayr millileşme $e^{44}$. Bunların en önemli sonucu ise, geleneksel olarak devletin ulusal yetkisine tabi olan içişleri alanlarının giderek daha çok uluslararası ilgi konusu haline gelerek diş müdahale ve denetimine açılmaya başlamasıdır.

\footnotetext{
42 Pâdraig Carmody, Rise of the BRICS in Africa: The Geopolitics of South-South Relations (London: Zed, 2013) 6.

${ }^{43}$ Stiglitz (2002), Globalization 10.

${ }^{44}$ Shephan Hobe, 'New Trends of International Law in the Era of Globalization' (2010) 3 Collected Courses of the Xiamen Academy of International Law 9-10.
} 
Mali piyasaların küreselleşmesi, bir evrimsel geçiş sürecidir ve bazı unsurları içerir. İlk olarak para, finans, yatırım ve ticaretin serbestleşmesi, sermaye akışı ve mali sistemlerin Bretton Woods sisteminin getirdiği kapalı ve sabit yapıdan tedrici ve kapsamlı olarak kurtulmasını sağlamıştır. İkinci olarak, giderek finansal akışın bankalardan sermaye piyasalarına geçmesiyle hem ulusal hem de uluslararası olarak varlığa dayalı menkul kıymet çıkarmak süreci (mali menkulleştirme) ortaya çıkmıştır. Üçüncü olarak, teknolojik buluşlar bütün dünyada bilgi akışını hızlandırmış ve eskiden birbirinden yalıtılmış durumda olan mali sistemler ve piyasaların birbiriyle olan bağlantısını arttırmıştır. Dördüncü olarak, finansal buluşlar menkulleri kıymetleştirmede yeni yöntem ve finans ürünleri ile sürekli değişen finans piyasaları ve katılımcıların ihtiyaçlarını karşılamayı başarmıştır. Beşinci olarak, özelleştirme ile hükümetlerin iç piyasalar üzerindeki etki ve denetimi merkezi ekonomik karar verme rolünün ortadan kalkmasıyla azalmıştır ve bu piyasaların bir uluslararası mali varlık ve refah kaynağı haline gelmesinin yolu açılmıştır ${ }^{45}$.

Özellikle 1980'li yıllarda bu uluslararası açılma, kamu maliyesindeki serbestleşme ve bilişim teknolojisindeki buluşlarla finansal küreselleşmeyi fevkalade hızlandırmıştır. Aslında 1950'lerden itibaren Avrupa para piyasalarının açılmasıyla sermaye piyasalarının serbestleşmesi başlamıştı. Ancak 1970'lerin başında Bretton Woods sisteminin çökmesiyle, ortaya çıkan para değişim riskinin özelleştirilmesi, önce döviz değişim piyasalarının hacminin artmasına, daha sonra 1980'lerde küresel tahvil piyasalarının ve nihayet 1990'ların başında ise, küresel hisse senetleri piyasalarının yaratılmasına neden olmuştur. 2000 yılı itibarıyla küresel menkul kıymetlerin değeri 150 trilyon ABD dolarına ulaşarak, bütün dünyanın toplam üretim çıktısı değerinin beş misline çıkmıştır. ${ }^{46}$ Ancak finansal küreselleşme, sadece küresel finansal piyasaların büyümesini sağlamakla kalmamış, bunun yanında hem bütün bu piyasalar içerisindeki mevcut mal miktarı ve fiyatlardaki dalgalanmaları ve hem de bu piyasalar ve ulusal sınırlar arasındaki akışı da arttırmıştır. Böylece bir yerdeki yerel krizin bir başka yere sirayet etmesi, kolayca büyümesi ve hızla yayılma etkisi göstermesi kaçınılmaz

\footnotetext{
${ }^{45}$ Arner (2008), 'The Developing Discipline' 251-2.

${ }^{46}$ Singh (2000), Taming Global Financial Flows 17.
} 
bir hale gelmiştir ${ }^{47}$. Finansal küreselleşme, neoliberalist okulun 'liberalleştirdiği' piyasalarda yeni küresel mahiyette krizlerin doğmasına neden olmaya başlamıştır ${ }^{48}$. Weber'e göre, finansal krizlerin küresel nitelik kazanarak farklı görünümler altında kısa aralıklarla bir çok ülkeye sirayet etmesinin temel nedeni, istikrarlı bir düzenleyici hukuki çerçevenin uygun bir biçimde ihdas edilmemiş olmasındandır; bu eksiklik piyasaya katılımcıların yaratılan bu liberal ortamı kötüye kullanmasına imkan sağlamaktadır ${ }^{49}$.

İkinci Dünya Savaşından sonra, başlangıçta Avrupa para piyasalarının açılması ile değiştirilebilirliğin (convertibility) artması yüzünden bazı gelişmiş ülkelerin paralarındaki (özellikle Sterlin) devalüasyon, bu büyük endüstriyel ekonomilerin ötesinde sınırlı etki yaratmışt1 $^{50}$. Ancak 1970'li yıllarda petrol ambargolarının olumsuz etkisi bütün petrol ithal eden ekonomilerde ödemeler dengesinde bir krize yol açmıştır ${ }^{51}$. Yine bu tarihlerde Şili'de demokratik seçimle iktidara gelen Salvador Allende hükümetinin sosyalist politikalarına karşı askeri ihtilal düzenleyen General Pinochet'in askeri cunta idaresi tarafından uygulanan neoliberal ekonomik yapılanmanın başarısızlıkla sonuçlanmasına rağmen ${ }^{52}$ yine finansal liberalleşme dayatmasına maruz kalan Meksika'nın 1982 yılında dış (tahvil) borçlarını tabi olduğu serbest piyasadaki yüksek faiz oranları yüzünden ödeyememesi yeni tür bir kriz (sovereign debt crisis) ortaya çıkartmıştır ${ }^{53}$. Nitekim Latin Amerika, Afrika, Asya ve Doğu Avrupa'da dış borçlarını ödeyemeyen pek çok devlet, kendisini

${ }^{47} \mathrm{Bu}$ sürecin geniş bir özeti için bkz. John Eatwell, International Financial Liberalization: The Impact on World Development (New York: UNDP Office of Development Studies, 1996).

${ }^{48}$ Finansal krizlerin tarihsel evrimi için bkz. Charles P. Kindleberger and Robert Z. Aliber, Manias, Panics and Crashes: A History of Financial Crises $\left(5^{\text {th }}\right.$ edn, New Jersey: John Wiley \& Sons, 2005).

${ }^{49}$ Rolf H Weber, 'Challenges for the New Financial Architecture' (2001) 31 Hong Kong L. J. 242.

${ }^{50}$ Bordo (1993), 'The Bretton Woods International Monetary System' 42-5.

${ }^{51}$ Singh (2000), Taming Global Financial Flows 129-30; Lowenfeld (2008), International Economic Law 668-71.

${ }^{52}$ Klein (2007), The Shock Doctrine 7 ve 63 et seq.

${ }^{53}$ Rumu Sarkar, International Development Law: Rule of Law, Human Rights and Global Finance (Oxford: Oxford University Press, 2009) 264-72; Lowenfeld (2008), International Economic Law 671-7. 
üçüncü dünya borç krizinin içerisinde bulmuştur ${ }^{54} .1987$ y1lında New York Wall Street borsasında başlayan vadeli işlem ve opsiyon piyasasının çöküşü, bir anda dünya çapında bir krize yol açtı ve ancak hükümetler tarafından piyasalara çok büyük miktarda para sürülerek likiditenin sağlanmasıyla önlenebildi ${ }^{55}$. Bir başka kriz türü ise 1992 ve 1993 yıllarında İngiltere ve İtalya'nın Avrupa Para Değişim Mekanizmasından çekilmek zorunda kalmasıla, Avrupa Birliği bölgesel para birimi sistemini krize götürmesinde yaşanmıştır ${ }^{56}$. 1994-95'de Meksika'da, Ağustos 1998'de Rusya'da, Ocak 1999'de Brezilya'da krizler para ve borçlanma, 1997-98'de Asya mali krizi ${ }^{57}$ ve 2001 'de Türkiye'de yaşanan kriz ise para, bankacılık ve dıș borçların bir karıșımı görünümünde ortaya çıkmıştır ${ }^{58}$.

Bütün bu krizlerin bir ortak yönü, Washington uzlaşmasının getirdiği finansal liberalizmin IMF ve Dünya Bankası tarafından şart koşulan yeniden yapılanma politikaları kapsamında uygulanmasının doğrudan bir sonucu olarak küresel bir yayılma şeklinde bir ülkeden diğerine sirayet (contagion) etmesidir. Finansal küreselleşmenin beraberinde getirdiği bu küresel krizler aslında en baştan beri uluslararası finansal denge ve istikrarı sağlamak amaciyla Bretton Woods sisteminin önlemek üzere kurulduğu türden krizlerdi ve küresel para/finansal idaresinin özellikle makroekonomik politikaların koordinasyonu, kriz yönetimi ve özel finans kuruluşlarının düzenlenmesi alanlarında yeniden yapılanması gereğini ortaya çıkartmışıır ${ }^{59}$. Sermaye piyasasının serbestleştirilmesi, ulusal ekonomilere sıcak para akışını arttııırken, buna

\footnotetext{
${ }^{54}$ Arjantin, Afrika ve Asya krizi incelemeleri için bkz. Wolff (2013-14), 'Failure of the International Monetary Fund' 107-19.

${ }^{55}$ Kindleberger \& Aliber (2005), Manias, Panics and Crashes 7.

${ }^{56}$ Steven Kettell, 'A Complete Disaster or a Relative Success? Reconsidering Britain's Membership of the ERM, 1990-1992', http://www2.warwick.ac.uk/fac/soc/pais/people/kettell/research/erm.pdf

${ }^{57}$ Riesenhuber (2001), The International Monetary Fund, 75-131; Kindleberger \& Aliber (2005), Manias, Panics and Crashes 156-8; Sarkar (2009), International Development Law 285-304, Lowenfeld (2008), International Economic Law 677-748.

58 Örneğin 1997-1998 ve 2007-2008 Asya krizlerinin incelemesi için bkz. Masahiro Kawai, 'Reform of the International Financial Architecture: An Asian Perspective' (2010) 55 Singapore Econ. Rev. 209-14; 2001 Türkiye krizi için bkz. Mihai Macovei, Growth and Economic Crises in Turkey: Leaving behind a Turbulent Past (Brussels: European Commission Economic Papers 386, October 2009) 1-36.

${ }^{59}$ Nakagawa (2010), 'Reconstructing' 110.
} 
bağlı riskleri de arttırmaktadır. Küreselleşmenin getirdiği finansal büyüme ve serbestlik özellikle gelişmekte olan ülkeler ve yükselen piyasalarda risk optimalleşmesinden ziyade mali kırılganlık yaratmıştır. Bu bakımdan BRICS Koşullu İhtiyat-Fonu kurulmasının arkasındaki düşünce, küreselleşen modern finansal piyasalarda artan risk unsurunu kontrol etmeye yönelik daha dayanıklı kurumlara ihtiyaç duyulmasıdır ${ }^{60}$.

\section{Yeni Bir Uluslararası Finansal Yapılanma İhtiyacı}

Washington uzlaşmasının getirdiği üç temel esasın - a) kamu harcamalarında kemer sıkma, b) kamu varlıklarının özelleştirilmesi ve c) serbest piyasa ekonomisine geçilmesi - IMF ve Dünya Bankasının uluslararası finans politikaları içerisinde 1980 ve 1990'lı y1llarda uygulanması, bir dizi ekonomik krizin birbiri ardına küresel düzeyde etki göstermesine neden olmuştur ${ }^{61}$. Nitekim sadece 1990'ların ortasından 2000 yılların başına kadar on ülkede Meksika (Şubat 1995), Arjantin (Nisan 1995 ve Mart 2000-Ocak 2003), Tayland (Temmuz 1997), Endonezya, Malezya, Filipinler (Kasım 1997-Ocak 1998 ve Ağustos 1998-Şubat 2000), Güney Kore (Aralık 1997), Rusya (Ağustos 1998), Brezilya (Aralık 1998) ve nihayet Türkiye'de (Aralık 1999-Şubat 2002) çok ciddi ekonomik krizler yaşanmıştır ${ }^{62}$.

$\mathrm{Bu}$ krizlerin bir ortak yönü, kamu sektöründeki cari hesaplarda bir dengesizlikten ziyade, gelişmekte olan ve yükselen ekonomilere giren portföy sermaye akışının yarattığı özel sektör borçlanması ve menkul piyasalarına yatırılan yabancı 'sıcak paranın' gayrı menkul piyasasının çökmesiyle sermaye piyasalarından çekilmesi sonucu bu yatırımlara yüksek riskle kredi sağlayan bankaların iflas etmesi neden olmasıydı ${ }^{63}$. Ancak daha önemli bir özellik ise, piyasaların açılması ve serbestleşmesi sonucu ters yöne dönen sermaye akışının miktarı ve çabukluğu ile piyasalara olan güvensizliğin yayılması ve finansal krizin diğer ekonomilere sirayet etmesiydi. Uluslararası mali düzenin

\footnotetext{
${ }^{60}$ Biziwick, Cattaneo \& Fryer (2015), 'The Rationale' 308.

${ }^{61}$ Stiglitz, IMF ve Dünya Bankasının özellikle Asya finansal krizindeki rolünü ilk elden eleştirisel olarak ayrıntılarıyla incelemektedir. Bkz. Stiglitz (2002), Globalization and its Discontents 53-132.

${ }^{62}$ Luc Laeven and Fabian Valencia, Systemic Banking Crises: A New Database, Washington, DC: IMF Working Paper WP/08/225, November 2008.

${ }^{63}$ Kern Alexander, Rahul Dhumale and John Eatwell, Global Governance of Financial Systems: The International Regulation of Systemic Risk (Oxford: Oxford University Press, 2006) 29.
} 
küreselleşmesinde IMF ve Dünya Bankasının kriz öncesi ve sonrasında takip ettiği makroekonomik politikalarıyla bu durumun meydana gelmesinde ve krizleri idaresindeki rolü eleștirilerin odağ gelmiştir $^{64}$. Küreselleşmenin yarattığ1 finansal bütünleşmenin özellikle gelişmekte olan ve yükselen ekonomileri maruz bıraktığı sistemik risk, iki taraflı ticari ilişkilerin yerine ağırlık kazanmaya başlayan çok taraflı yeni mali düzenin idaresinde Bretton Woods sisteminin kurumlarının artık yeterli olmadığını göstermiştir. Nitekim 1997-1998 Asya finansal krizinden sonra, Eichengreen ve diğer bazı yazarlar, mevcut uluslararası finansal yapıyı ve IMF'nin makroekonomik performansını sorgulamaya başlamış ve yerine 'yeni bir uluslararası finansal mimarlığı' önermişlerdir ${ }^{65}$. Bu görüsş mali krizi yaşayan Asya devletleri tarafından paylaşılmış ve Bretton Woods ile kurulan mevcut resmi finansal sistem içerisinde özellikle IMF tarafından malların, hizmetlerin, ve sermayenin ülkeler arasında pürüzsüz akışının sağlanamadığı ve küresel finansal istikrarın korunamadığı inancı hakim olmaya başlamıştır. Öyle ki 'IMF'nin krizden etkilenen ekonomilerine krizi idare etmek ve kurtulmak için yardım etmekte etkisiz kaldığı ve hatta krizin daha da ağırlaşmasına' neden olan makroekonomik politikaları dayattı̆ğ hususunda görüş birliği ortaya çıkmıştır ${ }^{66}$. Reform talepleri özellikle küresel finansal idare yapısı ve bunun içerisinde IMF ve Dünya Bankasının yapısı ve işleyişinde şeffaflık, IMF'nin ulusal ekonomileri gözlemlemesi, likidite yardımı, kredi yardımı koşulları üzerinde yoğunlaşmıştır ${ }^{67}$. Ancak bu konularda batılı gelişmiş devletlerin mevcut uluslararası finansal düzeni reform konusundaki isteksizliği ve 2008-2012 yılları arasında önce ABD'de başlayan 'subprime mortgage' (yüksek risk-yüksek faizli ev kredisi) krizi gelişmiş ekonomilerde yatırım bankalarının iflası ile küresel bir etki kazanarak, bunlardan kısa dönemli sermaye ithali ihtiyacı içerisinde olan veya Amerikan ve Avrupa piyasalarına mal ihraç etmekte olan yükselen

\footnotetext{
${ }^{64}$ Wolff (2013-14), 'Failure of the International Monetary Fund' 116-9; Stiglitz (2002), Globalization and its Discontents 89-132.

${ }^{65}$ Eichengreen (1999), Toward a New International Financial Architecture 8-15; Weber (2001), 'Challenges for the New Financial Architecture' 241-50; Nathan M. Jansen, 'Crises, Conditions, and Capital: The Effect of International Monetary Fund Agreements on Foreign Direct Investment Flows' (2004) 48 J. Conflict. Resol. 194-200; Arner (2008), 'The Developing Discipline' 255-62.

${ }^{66}$ Kawai (2010), 'Reform of the International Financial Architecture' 207.

${ }^{67}$ Nakagawa (2010) 'Reconstructing' 99-102.
} 
ekonomilere de sirayet etmesi, doğu Asya'da bölgesel bir finansal yapılanmanın ortaya çıkmasına zemin hazırlamıştır ${ }^{68}$.

$\mathrm{Bu}$ bağlamda BRICS, geleneksel uluslararası ekonomik düzen içerisinde batılı gelişmiş ülkelerin hakimiyetine karşı bir tepki görünümünde ortaya çıkmıştır ve neoliberal kapitalist görüşe dayanan Washington uzlaşmasına karşı küresel ekonomik ve finansal idare için bir alternatif yaklaşımı temsil etmektedir ${ }^{69}$. Böylece, yeni bir uluslararası finansal mimarinin hukuksal ve kurumsal yapısının oluşturulmasında normatif etkiye sahip bir belirleyici unsur olma konumuna gelmiştir ${ }^{70}$.

\section{BRICS}

BRIC kavramı, ilk kez 2001 yılında Brezilya, Rusya, Hindistan ve Çin arasında geniş anlamda bir ekonomik gruplaşma düşüncesini ifade etmek üzere ortaya atılmıştır. Bu önerinin sahibi olan Goldman Sachs yatırım bankası ekonomistlerinden $\mathrm{Jim} \mathrm{O}^{\prime} \mathrm{Neil}$, gelecek yarım yüzyılda küresel eğilimlerin ne olabileceğini tahmin etmek üzere hazırlanan bir ekonomik model içerisinde, bu dört ülkenin küresel ekonomide giderek belirleyici bir rol oynayacağını öngörmüştür ${ }^{71}$. Daha sonra aynı ifade, küresel ekonominin çekim merkezi dinamiklerinin gelişmiş G-7 ekonomilerinden gelişmekte olan ülkelere doğru kaymasının bir sembolü olarak kullanılmaya başlanmıştır ${ }^{72}$. Dünya ekonomisinin gelecek 50 yıldaki evrimi içerisinde ortaya çıkabilecek dinamikleri inceleyen 2003 tarihli Goldman Sachs raporu, BRIC ülkelerinin en büyük küresel ekonomik bir güç haline gelerek, yeni talep artışı ve harcama kapasitesi yaratacağını iddia etmiştir ${ }^{73}$. Öyle ki, 40 yıldan az bir sürede Çin ve Hindistan'ın mal ve hizmetlerin üretilmesi ve sunumunda, Brezilya ve Rusya'nın ise ham madde arzında dünyada hakim konuma geleceğini ve

${ }^{68}$ Kawai (2010), 'Reform of the International Financial Architecture' 211-4.

${ }^{69}$ Nicollette Cattaneo, Mayamiko Biziwick \& David Fryer, 'The BRICS Contingent Reserve Arangement and Its Position in the Emerging Global Financial Architecture' (2015) 10 Policy Insights 2.

70 Sonia E. Rolland, 'The BRICS' Contributions to the Architecture and Norms of International Economic Law' (2013) 107 Proceedings ASIL 164.

${ }^{71}$ Jim O'Neill, Building Better Global Economic BRICs (Goldman Sachs, Nov. 30, 2001), http://www.goldman- sachs.com/our-thinking/archive/archive-pdfs/build-betterbrics.pdf.

72 Danny Quah, 'The Global Economy's Shifting Centre of Gravity' (2011) 2 Global Policy 4-5.

${ }^{73}$ Dominic Wilson and Roopa Purushothaman, Dreaming with BRICs: The Path to 2050 (Global Economics Paper No.99, Goldman Sachs, Oct. 1, 2003) 2. 
BRIC ekonomileri toplamının dolar bazında G-7 ülkelerinden daha büyük olacağını tahmin etmiştir. Nitekim 2011 yılı itibarıyla, BRIC ülkelerinin toprakları dünyanın $\% 26$ 'i, nüfusu $\% 42$ 'si ve toplam gayrı safi yurtiçi milli hasılası 20 trilyon dolar ile \%26'sının üzerinde seyretmekteydi ${ }^{74}$. Bu görünümü ile dört ülke, en büyük ve en hızlı büyüyen 'yükselen piyasa ekonomileri' arasında yer alarak, 2000-2008 yılları arasında küresel ekonomik büyümenin $\% 55$ 'ni teşkil etmiştir ${ }^{75}$. Bu tahminler büyük ölçüde daha önce arka planda meydana gelen ve gelişmekte olan bu ülkelerin ekonomilerinde 1990'lar boyunca yaşanan köklü bazı yapısal reformlar dikkate alarak yapılmıştır. Ancak o tarihlerde dört ülke arasında herhangi bir alternatif ekonomik blok yaratmayı hedefleyen bir yakınlaşma veya resmi işbirliği öngörülmemişti. BRIC'in kurumlaşması düşüncesi daha sonra 2001 ve 2006 yılları arasında gayrı resmi olarak tartışmaya açılmış ve ilgi uyandırmıştır ${ }^{76}$.

Kurumlaşma yönündeki ilk resmi istişare, Rusya'nın inisiyatifi ile uluslararası güncel sorunları tartş̧mak üzere BRIC devletleri dışişleri bakanlarının Eylül 2006 tarihinde New York'ta düzenlenen 61. BM Genel Kurulu toplantısı dolayısı ile bir araya gelmeleriyle başlamıştır. Aynı vesileyle her yıl dişişleri bakanları seviyesinde yapılan görüşmeler, 2008 yılında maliye bakanları nezdinde küresel finansal krizlerin değerlendirildiği bir paralel sürece genişletilmiştir. Uluslararası ekonomik sorunların diğerlerinin arasında ağırlık kazanmasına, BRIC devletlerinin finansal ilişkilerde hızla artan rolü etkili olmuştur. Şöyle ki, 2000-2008 arasındaki dönemde dünyadaki toplam ekonomik çıktıda meydana gelen artışın \%60'1, gelişmekte olan veya geçiş aşamasındaki ekonomilerde ortaya çıkarken, bunun yarısından fazlasını BRIC sağlamıştır ve aynı dönemde küresel gayri safi hasıla GDP içerisindeki payı \%16'dan \%22'ye çı kmıştır $^{77}$. Bu en üst düzeydeki resmi görüşmeler sonucu, 16 Haziran 2009 tarihinde Rusya'nın Yekaterinburg şehrinde toplanan BRIC devlet başkanları arasındaki zirve bu birlikteliği uluslararası hukuka dayanan daha demokratik ve çok taraflı dünyada bütün devletlerin eşitlik, karşılıklı

\footnotetext{
${ }^{74}$ Müslüme Narin ve Dilek Kutluay, 'Değişen Küresel Düzen: BRIC, 3G, N-11 Ülkeleri' (2013) Ocak/Şubat Dosya 40-5.

${ }^{75}$ Carmody (2013), Rise of BRICS in Africa 2.

${ }^{76}$ Suresh P. Singh and Memory Dube, BRICS and the World Order: A Beginner's Guide (May 30, 2014) 6, http://dx.doi.org/10.2139/ssrn.2443652

77 Cynthia Roberts, 'Challengers or Stakeholders? BRICs and the Liberal World Order, Introduction' (2010) 42 Polity 1-3.
} 
saygı, işbirliği, eşgüdümlü eylemi ve toplu karar alması ilkeleri üzerinde resmileştirmek için ilk adımı atmışıır ${ }^{78}$. Güney Afrika'nın gruba katılması, 2010 yılında Brezilya'da toplanan BRIC devlet başkanları ikinci zirvesinde yapılan davet üzerine gerçekleşmiştir ve böylece günümüzdeki üye sayısiyla BRICS bir siyasi forum olarak resmen 2011 tarihinde doğmuştur ${ }^{79}$.

Sovyetler Birliğinin dağılmasından sonra uluslararası ilişkilerde kaybolan güçler dengesi, yerini 'tek kutuplu' bir düzen içerisinde Amerikan hegemonyasına bıraktığı görülmüsstü. Ancak aynı dönemde BRIC devletlerinin toplam nüfus, şehirlerde yaşayan nüfus, demir-çelik üretimi, enerji tüketimi, asker sayısı ve askeri harcamalarından oluşan ulusal güç kapasitesi indeksinin toplamı G-5 grubunun toplamından fazla olduğu gibi, Çin'in ABD ile arasındaki farkı kapatmaya başlaması, gelişmekte olan ekonomilerde ve yükselen piyasalarda 'çok kutuplu' bir uluslararası sistem kurulması arayışının sesli telaffuz edilmesine neden oldu. $\mathrm{Bu}$ durum siyasi realist teori bakımından değerlendirildiğinde, BRICS küresel idari yapıda tek kutupluluğa karşı çok kutuplu 'yeni uluslararası finansal mimariyi' sağlamak üzere alternatif bir 'süper güç' rolüne soyunmaktadır ${ }^{80}$. Nitekim Laïdi, BRICS'i çoğu kez birbirine rakip olan güçlerin heterojen bir koalisyonu olarak görmektedir ve ona göre, bir araya gelmelerinin ortak temel siyasi amacı ise Batının hegemonik iddialarını çürütmektir. Bunu yaparken de Batı neoliberalizminin küreselleşme ile hedef aldığı siyasi egemenlik ve bağımsızlık ilkesini korumak isterler. Bu bakımdan BRICS, aslında küreselleşmenin ve Irak savaşının bir ürünüdür: ekonomik boyutu küreselleşmenin doğrudan bir sonucu iken, Irak savaşı ise stratejik dinamiğini teşkil etmektedir ${ }^{81}$.

Ancak bu ekonomik ve hatta jeopolitik gruplaşmanın bir siyasi forum olmanın getirdiği küresel finans idaresinde bir gayrı resmi dayanışmanın ötesinde, uluslararası hukuk kişiliği kazanarak makroekonomik politikaları uluslararası ekonomi hukuku içerisinde

\footnotetext{
${ }^{78}$ Singh \& Dube (2014), BRICS and the World Order 7.

${ }^{79}$ Stuenkel Oliver, 'South Africa's BRICS membership: A win-win situation?' (2013) 7 African Journal of Political Science and International Relations 310-1.

${ }^{80} \mathrm{Bu}$ teorik perspektifin küresel politik ekonomi bakımından ayrıntılı tartışması için bkz. Leslie Elliot Armijo, 'The BRICs Countries (Brazil, Russia, India, and China) as Analytical Category: Mirage or Insight?' (2007) 31 Asian Perspective 14-29.

${ }^{81}$ Zaki Laïdi, 'BRICS: Sovereignty Power and Weakness' (2012) 49 International Politics 614-9.
} 
etkileyebilme kabiliyeti oldukça yoğun bir akademik tartışma konusu olmuştur $^{82}$. Özellikle pek çok yönüyle bu ülkelerin arasındaki farklılıklar ve ayrışmaların bunların ortak olan özelliklerinden fazla olması ${ }^{83}$ ayrıca şimdiye kadar ulus-üstü yapılanma içerisinde örgütlenmekten kaçınmaları veya ortak meselelerde tekdüze bir siyasi duruş sergilemekten kaçınmaları, BRICS' in kurumsal ve hukuksal kimliğinin sorgulanmasına sebep olmuştur ${ }^{84}$. Buna rağmen BRICS, uluslararası ekonomi hukukunun içeriği ve kurumsal yapısına özellikle mali hukuk, ticaret hukuku, yatırım hukuku, uluslararası ekonomik düzenin idaresine ve kurumlarına fiilen katkıda bulunmaktadır. Uluslararası ilişkilerde bir forum olarak siyasi kimliğinin yanında BRICS devletlerinin kurduğu Yeni Kalkınma Bankası ve BRICS Koşullu İhtiyat-Fonu Düzenlemesi, bir uluslararası örgütlenme süreci içerisinde hukuk kişiliği kazanmaya yönelik bir incelemeyi ve buna bağlı tartışmaları gündeme getirmektedir ${ }^{85}$.

Çalışmanın devamı, bu uluslararası finansal yapılanma bağlamı içerisinde Koşullu İhtiyat-Fonu Düzenlemesini Kuran Andlaşmanın, uluslararası ekonomi hukuku içerisinde mevcut Bretton Woods kurumlarına etkisi ve yeni uluslararası finansal mimarinin şekillenmesine olası katkılarını incelemeye ayrılmıştır.

\section{Koşullu İhtiyat-Fonu Düzenlemesi}

1. Andlaşmanın Konu ve Amacı

Andlaşmanın konusu, kendi kendisini idare eden bir koşullu ihtiyat fonu düzenlemesi yapmaktır. Bu düzenleme ile hedeflenen, kısa dönemli ödemeler dengesindeki daralma ve baskıların önüne geçmek, karşılıklı destek sağlamak ve bu şekilde mali istikrarı daha da güçlendirmektir. Tarafların niyeti iki türlü ifade edilmiştir: bir yandan, küresel mali güvenlik ağını sağlamlaştırmak; diğer yandan ise, mevcut uluslararası para ve finans düzenlemelerini tamamlayıc1 bir rol üstlenmektir ${ }^{86}$. Öngörülen hedeflerin, sadece BRICS üyeleri arasındaki mali ilişkilerle sınırlı kalmayarak küresel bir uygulama alanı içermesi, bu devletlerin

\footnotetext{
${ }^{82}$ Andrew Cooper \& Asif B. Farooq, 'BRICS and the Privileging of Informality in Global Governance' (2013) 4 Global Polity 128-32.

${ }^{83}$ Cattaneo, Biziwick \& Fryer, 'The BRICS Contingent Reserve Arrangement' 2-3.

${ }^{84}$ Marcos Galvão, 'Brazil, Russia, India, and China: Brand BRIC Brings Change' (2010) 66 The World Today 13-5.

${ }^{85}$ Rolland (2013), 'The BRICS' Contributions' 168-70.

${ }^{86}$ Giriş, Treaty for the Establishment of a BRICS Contingent Reserve Agreement, Fortaleza, 15 July 2015.
} 
geniş anlamda çok taraflı mevcut uluslararası mali sisteme bağımlılıkları kadar, kendilerini birlikte 'küresel kalkınmanın güçlü bir unsuru' olarak görmelerinden kaynaklanmaktadır ${ }^{87}$.

Kurulan Koşullu İhtiyat-Fonu Düzenlemesi özünde bir 'çerçeve' olarak düşünülmüştür ve bu yaklaşımın uluslararası kişilik bakımından sonuçları vardır. Düzenleme çerçevesinin amacı Andlaşmanın 1. maddesinde, 'ödemeler dengesindeki kısa dönemli gerçek veya potansiyel daralma ve baskılara' karşı likidite ve önleyici tedbirler yoluyla destek sağlamak olarak tanımlanmıştır ${ }^{88}$. Bu açıdan bakıldığında, düzenlemenin gayesinin aslında sınırlı olduğu görülür. En azından IMF’nin amaçları kadar geniş ve kapsamlı olmadığı kesindir. IMF'nin amaçları arasında, 'danışma ve birlikte çalışma mekanizması içeren daimi bir kurum vasıtasıyla uluslararası parasal işbirliğini teşvik etmek, uluslararası ticaretin dengeli büyümesi ve gelişmesine imkan vermek, ve böylece istihdam ve reel gelirin yüksek seviyelere çıkması ve tutulmasını teşvik etmek...' ve dünya genelinde yoksulluğu azaltmak gibi bazı makroekonomik edimler sayılmıştır ${ }^{89}$. Oysa küresel ekonomik ve finansal yönetimine bu tür uzun dönemli katkılardan çok, Koşullu İhtiyat-Fonu Düzenlemesinin mali istikrarı güçlendirmekle yetindiği görülür; karşılıklı mali destek ise, öncelikle BRICS üyesi devletler arasındaki işbirliğinin önemli bir adımı olarak öngörülmüştür ${ }^{90}$. IMF'ye yüklenen görevlere kıyasla, Koşullu İhtiyat-Fonu Düzenlemesinin kendisini mevcut uluslararası para ve finans sisteminin tamamlayıcı bir işlevi olmak beklentisi ile sınırladığı söylenebilir. Daha ziyade, ulusal bütçe açı̆̆ının temel nedenlerinden biri olan ödemeler dengesindeki kısa dönemli daralma ve baskılara karşı destek fonu sağlamaya odaklandığı görülür. $\mathrm{Bu}$ bakımdan kısmen de olsa IMF'nin ödemeler dengesindeki açıkları düzeltmek üzere geçici mali kaynaklar sunması işlevini görür ${ }^{91}$.

Koşullu İhtiyat-Fonu Düzenlemesi ve IMF statüleri arasındaki konu ve amaç bakımından bu kısa karşılaştırma, BRICS'in küresel ekonomik

\footnotetext{
${ }^{87}$ Nitekim, Rusya'nın Ufa şehrinde toplanan VII. BRICS zirvesi, "BRICS Ortaklığ 1 Küresel Kalkınmanın Güçlü bir Unsuru" teması altında düzenlenmiştir.

${ }^{88}$ 1. Madde, Treaty for the Establishment of a BRICS Contingent Reserve Agreement, Fortaleza, 15 July 2015.

${ }^{89}$ Madde I (i) ve (ii), International Monetary Fund, Articles of Agreement of the International Monetary Fund, 1944 (Washington, D.C.: IMF 2011) 2.

${ }^{90}$ Ufa Declaration para.16.

${ }^{91}$ Madde I (v), Articles of Agreement of the International Monetary Fund 1944.
} 
düzen üzerinde uyandırabileceği etkinin bir göstergesidir. Andlaşmanın uygulama kapsamının sadece kısa dönemli mali meseleler ile sınırlı tutulmuş olması, bu etki derecesinin kriz odaklı çözümlerin ötesinde uzun dönemli kalıcı makroekonomik değişiklikler yaratmak niyetinin bulunmadığı şeklinde yorumlanabilir.

\section{Kurumsal İnceleme}

Koşullu İhtiyat-Fonu Düzenlemesini kuran Andlaşmanın kurumsal çerçevesinin incelenmesi, faaliyetlerin icrası bakımından iki idari husus üzerinde durmayı gerektirir. Bunlar kurulan çerçevenin idari yapısı ile karar verme usulüne ilişkin özellikleridir. $\mathrm{Bu}$ özellikler bakımından sağlanabilecek etkinlik düzeyi, Koşullu İhtiyat-Fonu Düzenlemesinin BRICS üyesi devletlerin küresel ekonomik meseleler üzerinde daha güçlü bir söz ve temsil hakkı kazanmak iddialarını ne ölçüde yerine getirebileceğinin bir göstergesi olarak ele alınabilir.

\section{a. İdari Yapısı}

BRICS Koşullu İhtiyat-Fonu Düzenlemesinin idari yapısı iki ana organdan oluşur: i. Guvernörler Konseyi ve ii. Daimi Komite ${ }^{92}$ İdari açıdan IMF'nin yapısını teşkil eden Guvernörler Kurulu ve İcra Kurulundan farklı olmadığ 1 görülmektedir ${ }^{93}$.

\section{i. Guvernörler Konseyi}

Koşullu İhtiyat-Fonu Düzenlemesine ilişkin Andlaşma, Guvernörler Konseyinin her bir BRICS üyesi devlet tarafindan atanacak bir Guvernör ile bir yedek Guvernörden teşkil olacağını öngörür ${ }^{94}$. Konsey, Koşullu İhtiyat-Fonu Düzenlemesinin en yüksek seviyede karar verme organı olarak düşünülmüsşür ve stratejik kararlardan sorumlu olacağı açıkça ifade edilmiştir. Nitekim guvernörlerin maliye bakanı, merkez bankası müdürü veya buna denk olan seviyede bir mevkie sahip kişilerden atanması şart koşulmuştur. Bu şartın IMF anlaşmasında aranmadığı görülür. IMF üyesi devletlerin, kendi belirleyecekleri bir tarzda üye atayabilecekleri kabul edilmiştir ${ }^{95}$. Ancak uygulamada IMF Guvernörler Kurulunun geleneksel

\footnotetext{
${ }^{92}$ Madde 3 (a), Treaty for the Establishment of a BRICS Contingent Reserve Agreement, Fortaleza, 15 July 2015.

${ }^{93}$ XII. Madde, Bölüm 1, Articles of Agreement of the International Monetary Fund 1944.

${ }^{94}$ Madde 3 (b), Treaty for the Establishment of a BRICS Contingent Reserve Agreement, Fortaleza, 15 July 2015.

95 XII. Madde, Bölüm 2 (a), Articles of Agreement of the International Monetary Fund 1944.
} 
olarak üye devletlerin maliye bakanları veya merkez bankası başkanlarından oluştuğu görülür ve yılda bir kez olağan toplanır. IMF içerisinde bir başka organa verilmemiş olan bütün yetkiler Guvernörler Kuruluna verilmiştir ama açıkça devredilemeyeceği öngörülenlerin dışındaki bütün yetkiler uygulamada icra kurulu tarafından kullanılır ${ }^{96}$.

\section{ii. Daimi Komite}

Koşullu İhtiyat-Fonu Düzenlemesinin işleyişi ve idari seviyedeki kararlarından sorumlu olan Daimi Komite, olağan işlerin yürütülmesi ve icrai meseleler ile ilgili faaliyetlerde bulunmak üzere görevlendirilmiştir ${ }^{97}$. Özellikle Düzenlemenin temel işlevi olan likidite ve önleyici tedbirler yoluyla destek taleplerini ve yenilenmesini değerlendirmek ve karara bağlamak hususunda yetkilidir ${ }^{98}$. BICS üyesi her bir devlet tarafindan atanan bir direktör ve bir yedek direktörden meydana gelir. Üye devlet aksine bir karar vermemişse, atayacağı direktörleri normal olarak kendi merkez bankası mensupları arasından seçer. Bu bakımdan IMF'nin icra organı olan Yönetim Kurulu ile bir benzerlik içerisindedir.

BRICS Düzenlemesinden farklı olarak, IMF Yönetim Kurulu 189 üye devlet içerisinden coğrafi ve siyasi olarak uyumlu devlet gruplarını temsilen 24 direktörden oluşur. $\mathrm{Bu}$ direktörlerin 16 tanesi seçimle gelirken, diğerleri en yüksek kotalara sahip olan devletler tarafindan atanır. Ancak 2008 tarihli bir değişiklikle en yüksek kotaya sahip olan ABD, Japonya, Almanya, Fransa ve İngiltere tarafından atanan beş direktörün dışında diğer üye devletlere tahsis edilen kontenjan 19'a çıkarılmıştır. 2010 tarihli bir reform kararı ile bu imtiyazlı devletleri temsil eden beş direktör kategorisinin uygulamadan kaldırılmasına ve bazı batı Avrupa devletlerinin temsilinin gelişmekte olan devletler lehine azaltılmasına karar verilmiştir ${ }^{99}$. Yönetim Kurulu, para fonunun günlük işleyişini temin etmekten sorumludur. Bu amaçla, Guvernörler Kurulu tarafından kendisine verilen her türlü yetki ile donatılmıştır ${ }^{100}$. Bir anlamda icra direktörleri IMF'nin örgüte bağl1 çalışan ve bağımsız

\footnotetext{
${ }^{96}$ Lowenfeld (2008), International Economic Law 602.

${ }^{97}$ Madde 3 (c), Treaty for the Establishment of a BRICS Contingent Reserve Agreement, Fortaleza, 15 July 2015.

${ }^{98}$ A.g.e., Madde 3 (c) (ii) ve (iii).

99 Matthias Herdegen, Principles of International Economic Law (Oxford: Oxford University Press, 2013) 439.

${ }^{100}$ XII. Madde, Bölüm 3 (a), Articles of Agreement of the International Monetary Fund 1944.
} 
personeli ile siyasi olarak kendi devletlerini temsil eden Guvernörler arasında bir konumdadirlar. Bir yandan, kendilerini gönderen devletten talimat alma durumunda oldukları izlenimini verirler. Öte yandan, bu direktörler IMF bünyesinde yerleşik olarak görev yaparlar ve Washington'da yaşarlar. Fonun günlük işlerinin yürütülmesi için gerekli görülen sıklıkta toplanır ve karar alırlar. Bu hizmetlerin karşılığında maaşlarını IMF'den aldıkları için kendi devletlerine bağımlı hareket ederek taraf olmaktan ziyade kuruma çalışan objektif davranan profesyonel kişiler olarak algılanırlar ${ }^{101}$. Bu güven ilişsisinin uygulamada işlerin akıcı yürütülmesi üzerinde önemli etkileri vardır.

Bu bakımdan Koşullu İhtiyat-Fonu Düzenlemesi bir farklılık içerir. Daimi Komitenin direktörlerinin tercihen her bir üye devlet tarafindan kendi merkez bankası mensupları arasından tayin edileceği öngörülmüştür. Ancak atanan direktörün, Fonun günlük idari işlerini çalışmakta olduğu merkez bankasındaki görevlerine ek olarak bir maaş almadan $\mathrm{m} 1$ yürüteceği, yoksa tam gün esasıyla mı görevlendirilecekleri henüz belirsizdir. Her halükarda, bu beş direktörün ve yedeklerinin Koşullu İhtiyat-Fonu Düzenlemesinin işlerinin icrası için faaliyet gösterebilecekleri sürekli ve ortak mekân gösterilmemiştir. Bu görünümüyle, genel merkez binası Washington'da bulunan ve hizmetleri tek elden yürüten IMF'den farklılık arz eder. Buna ek olarak, IMF bazı üye devletlerin nezdinde irtibat ofisi kurarak daimi temsilci ile birebir ilişkilerin yürütülmesini sağlar. Ancak Koşullu İhtiyat-Fonu Düzenlemesini Kuran Andlaşmanın 3. maddesi hükmü, bazı yazarlar tarafindan kurumsal ve izleme faaliyetleri bakımından, zaman içerisinde mali kaynakların toplandığı havuzun toplam miktarı ve IMF ile bağlantısının niteliği gibi hususlarla birlikte gerekli olan değişiklere imkan verecek esneklikte yorumlanmaktadır ${ }^{102}$. Nitekim ASEAN+3 grubu tarafindan kurulan Chiang Mai Initiative (CMI) tecrübesi bu yönde başarıyla gelişmiştir ${ }^{103}$.

\section{iii. Yönetim Faaliyeti}

Koşullu İhtiyat-Fonu Düzenlemesini Kuran Andlaşma, Guvernörler Konseyi ve Daimi Komite yanında doğrudan bir daimi sekreterlik veya hususi bir izleme birimi kurulmasını öngörmemiştir. Ancak kurucu

\footnotetext{
${ }^{101}$ Lowenfeld (2008), International Economic Law 603.

${ }^{102}$ Biziwick, Cattaneo \& Fryer (2015), 'The Rationale' 317.

${ }^{103}$ Kawai (2010), 'Reform of the International Financial Architecture' 230 et seq.
} 
Andlaşmanın 3 (b) (ix). maddesi gerekli görüldüğü takdirde bunların ihdas edilmesi hakkındaki kararı Guvernörler Konseyine yetkisine bırakmıştır ${ }^{104}$. Oysa muadil organlar IMF'in yönetim yapısı içerisinde mevcuttur. IMF'nin idari direktörü, Yönetim Kurulu tarafindan kurulun dışında ve guvernör olmayanlar arasından seçilir, IMF başkanıdır ve personelin başında kurumu yönettiği gibi, aynı zamanda Yönetim Kurulunun gündemini -belirlemeye yetkili olmasa da- idare eden ve normal olarak oy hakkı bulunmayan başkanıdır. IMF başkanı kurumu temsil eder ve sadece kuruma karş1 sorumludur; bir başka otoriteye tabi değildir $^{105}$. Ayrıca IMF uluslararası para sistemi içerisinde finansal krizlerin önüne geçebilmek ve istikrarı sağlamak için iki taraflı ve çok taraflı gözetim faaliyetini sürdürmek üzere bir izleme birimine sahiptir. İzleme işlevi, üye devletlerin ekonomik ve mali şartlarını inceleyerek, ulusal, bölgesel ve küresel finansal sorunlar değerlendirme yapmay1 içerir ${ }^{106}$. Böylece her bir üye devlet ile normal olarak senede bir kez ulusal makroekonomik ve yapısal politikalarının uygunluğu ve bu politikaların döviz kurları üzerindeki etkileri üzerinde danışma görüşmelerinde bulunur. Mali izleme programı kapsamında üye devletlere ekonomik istikrarı güçlendiren politikaları teşvik etmek, ekonomik ve mali krizlere karş1 kırılganlığı azaltmak ve fakirliği azaltarak yaşam standartlarını iyileştirmeye yönelik tavsiyelerde bulunmak imkânı ortaya çıkar ${ }^{107}$. Bu ilk elden bilgilendirme çok önemlidir. Koşullu İhtiyat-Fonu Düzenlemesinde daimi bir idari merkez ve izleme biriminin eksikliği, andlaşma ile amaçlanan çözümlerin sağlanması için gereken makroekonomik araştırma imkanlarının bu aşamada yetersizliğine işaret etmektedir. İdari teşkilatın başında bir liderin bulunmaması, Koşullu İhtiyat-Fonu Düzenlemesinin tek bir ağızdan güçlü temsili yerine BRICS devletlerinin fonun işleyişi üzerinde doğrudan etkilerini korumak arzusunda olduklarını gösterir. Müstakil örgüt yapılanmasının eksikliği, IMF karşısında gerçek bir alternatif olarak değerlendirilmesini zorlaştıran durumdur.

104 Madde 3 (b) (ix), Treaty for the Establishment of a BRICS Contingent Reserve Agreement, Fortaleza, 15 July 2015.

105 XII. Madde, Bölüm 4 (a-d), Articles of Agreement of the International Monetary Fund 1944.

${ }^{106}$ A.g.e., IV. Madde Bölüm 3.

${ }^{107}$ Alexander, Dhumale \& Eatwell (2006), Global Governance of Financial Systems 87-8. 


\section{b. Karar alma Nisabı}

i. Uzlaşı (Konsensüs)

Koşullu İhtiyat-Fonu Düzenlemesi, hem Guvernörler Konseyi ve hem de Daimi Komitede uzlaşı esasına dayanan bir oylama sistemi ihdas etmiştir. Her ne kadar Guvernörler Konseyinde karar alma usulü uzlaşma esasını istisnasız zorunlu kılmış ise de Daimi Komite kararları prensip olarak uzlaşı ile alınmalıdır. Fakat buna istisna teşkil edebilecek durumlar, bütün taraf devletler ile kredi sağlayacak olan taraf devletler ayrımı gözetilerek sayılmıştır. Şöyle ki, likidite ve ihtiyaten (önleyici) tedbir mahiyetindeki destek veya desteğin yenilenmesi taleplerinin onay1, kreditör devletlerin ağırlıklı oylarının salt çoğunluğuna tabi kılınmıştır ${ }^{108}$. Öte yandan, istisnai durumlarda onay şartlarından, teminat ve istenen belgelerden feragat etme kararları ile devletin kredisini kullanmak için paraya çevirme talebi ve andlaşmanın ihlalinden ötürü yaptırım uygulanması kararları sadece kreditör devletlerin uzlaşması ile alınabilir $^{109}$. Bunların dışında diğer bütün kararlar için taraf devletlerin uzlaşması ve aralarında görüş birliği aranır.

$\mathrm{Bu}$ düzenleme içerisinde taraf devletlerin Koşullu İhtiyat-Fonu kaynaklarına taahhüt ettikleri katkı payı aynı olmamasına rağmen -örneğin Çin'in 41 milyar ABD dolarına karşı Güney Afrika'nın 5 milyar ABD dolar1 bireysel kaynak tahhüdünde bulunmas1-, BRICS devletlerinin karar alma nisabı olarak görüş birliğine dayanan bir esası benimsediği görülmektedir. Dolayısıyla hem Guvernörler Konseyindeki stratejik kararlar ve hem de Daimi Komitedeki icra kararları bakımından, BRICS içerisinde oy ağılı̆̆ının üye devletlerarasında eşit olarak dağıldığı görülmektedir. $\mathrm{Bu}$ demokratik eşitlik içerisinde dengelenmiş oy sisteminin, Koşullu İhtiyat-Fonu Düzenlemesinin işleyişine yüksek derecede bir meşruiyet kazandırdığını söylemek mümkündür. Nitekim kararlarda eşitler arasında uzlaşı esası ile karar almak usulü, finansal ilişkilerde egemen eşit muamele görmek isteyen diğer devletler bakımından Koşullu İhtiyat-Fonu Düzenlemesine taraf olmayı cazip bir alternatif haline getirebilir ${ }^{110}$. Andlaşmanın kendisi bu olasılığ

\footnotetext{
${ }^{108}$ Madde 3 (c) (i) (ii), Treaty for the Establishment of a BRICS Contingent Reserve Agreement, Fortaleza, 15 July 2015.

${ }^{109}$ A.g.e., Madde 3 (c) (v) (vi) (vii).

${ }^{110}$ Biziwick, Cattaneo \& Fryer (2015), 'The Rationale' 317.
} 
düzenleyen bir hüküm içermektedir ${ }^{111}$. Böylece BRICS Koşullu İhtiyatFonu Düzenlemesi bütün devletlerin üyeliğine açık bir oluşumdur. Bununla birlikte eşitliğe dayanan bir uzlaşı sisteminin çok sayılı bir kurumda işlerliği şüphelidir. Buna iyi bir örnek Avrupa Birliğidir: oybirliği ile karar alma kuralı artan üye sayısı ile yerini nitelikli çoğunluk ve salt çoğunluk nisabı ile karar almaya bırakmıştır. Burada da Koşullu İhtiyat-Fonu Düzenlemesinin demokratik meşruiyeti ile sağladığı avantaj, çıkarları örtüşen nispeten az sayıda üye devletin taraf olmasıyla sınırlı olacaktır. Kendi şartları içerisinde ekonomik istikrar ve krizlere karşı finansal hazırlık içinde bulunmak isteyen gelişmekte olan devletlere küresel ekonomik politikaların şekillenmesinde daha çok söz hakkı ve temsil gücü sağlayabilir.

Buna karşılık, IMF içerisinde farklı bir ağırlıklı oya dayanan karar alma nisabı uygulanır ${ }^{12}$. Üye Devletlerin oyları, örgüte yaptıkları daha önce belirlenmiş bir mali katkı payı (kota) oranında ağırlığa sahiptir. Buna göre her devlete öncelikle 250 oy esas olarak tahsis edilir ve ayrıca 100,000 özel çekme haklarına (SDR) denk düşen bir kota miktarı karşılığ olarak bir oy ek olarak verilir. Aksine bir hükmün bulunmadığı hallerde, bütün kararlar kullanılan oyların çoğunluğu ile alınır ${ }^{113}$. Ancak üye devletlerin kotalarının değiştirilmesi ${ }^{114}$ veya Yönetim Kurulu üyesi direktörlerin sayısının değiştirilmesi ${ }^{115}$ gibi esaslı kararlar ise, Guvernörler Kurulunda mevcut oyların \%85 çoğunluğunu gerektirir. ABD tek başına toplam oyların \%16.74'üne sahip olduğu için, esaslı kararların alınması bakımından fiilen veto hakkı vardır. Dolayısıyla IMF'nin mevcut karar alma nisabında BRICS devletleri lehine yapılacak bir düzenleme, içerisinde ABD'nin de bulunduğu \%85 oranında nitelikli bir oy çoğunluğu ile alınabilir.

\footnotetext{
111 Madde 3 (b) (ii), Treaty for the Establishment of a BRICS Contingent Reserve Agreement, Fortaleza, 15 July 2015.

112 Beş büyük üye devletin ağırlıklı oyları, toplam oy hakkının \% 40 oranındandır. Brown (2003), 'IMF Governance' 134.

${ }^{113}$ Tenney \& Humphreys (2011), Historical Dictionary 309.

114 Madde III, Bölüm 2 (c), Articles of Agreement of the International Monetary Fund 1944.

${ }^{115}$ A.g.e., Madde XII, Bölüm 3(b).
} 


\section{IMF ve İdari Reform Ihtiyacl ${ }^{116}$}

IMF'nin 1997-1998 Asya finansal krizindeki tutumu, uluslararas1 finansal alandaki rolü ve meşruiyetini sorgulanır hale getirmiştir. ${ }^{117}$ Özellikle krizden etkilenen ülkelerde tepkilerin odağı haline gelen IMF'ye karşı duyulan derin güven bunalımını aşmak için, bir şekilde yükselen piyasa ekonomilerine ve gelişmekte olan ülkelere uluslararası mali düzenin işleyişi ve şekillenmesinde daha fazla söz ve temsil hakk1 tanımanın mevcut finans kurumlarına kaybettikleri itibar, güvenilirlik ve meşruiyeti yeniden kazandırabileceği düşünülmüştür ${ }^{118}$. Bunu gerçekleştirmek için ilk adım, 1999 tarihinde gelişmiş ülkelerin G-7 grubunun G-20'ye genişletilmesiyle, bazı yükselen piyasa ekonomileri veya gelişmekte olan ülkelerin uluslararası ekonomik ilişkilerde artan etkisinin tanınmasıdır. Böylece bu ülkeler, küresel finansın idari yapısı ve işleyişine ilişkin temel sorunların tartışıldığ 1 üst düzey forumlara dahil edilmiştir ${ }^{119}$. IMF finansal destek programlarına bağlanan, zarar eden bankaların kapatılması, kamu harcamalarında köklü kesintiler ve faiz oranlarının arttırılması gibi koşulların uygulamada ters sonuçlar vermesi ve ekonomik krizin ve sosyal etkilerini derinleştirmesi üzerine ${ }^{120}$ IMF'nin kendisi mali kaynak yetersizliği, idari vesayet ve meşruiyet sorunlarıyla karşılaşmış ve uluslararası finansal sistemin yapısal reform ihtiyacını telaffuz etmek zorunda kalmıştır ${ }^{121}$.

2008 tarihli G-20 zirvesi bildirisinin, bu amaçla önerdiği çeşitli alanlardaki reformlardan ${ }^{122}$ bir tanesi Bretton Woods uluslararas1 finans kurumlarında idari ve mali reformlar yapılması gereği olmuştur. Ancak bundan önce 2006 tarihinde Singapur'da yapılan IMF ve Dünya Bankas1 Ortak Yıllık Toplantılarında, ekonomik güçleri oranında en az temsil edilen Çin, Güney Kore, Meksika ve Türkiye'ye kota ve temsilde ad hoc

\footnotetext{
${ }^{116} \mathrm{Bu}$ husustaki öneriler için, Brown (2003), 'IMF Governance' 141-5.

${ }^{117}$ Stiglitz (2002), Globalization and its Discontents 89-132.

${ }^{118}$ Ngaire Woods, 'Global Governance after the Financial Crisis: A New Multilateralism or the Last Grasp of the Great Powers?' (2010) 1 Global Policy 53.

${ }^{119}$ Nakagawa (2010), 'Reconstructing' 115-6.

${ }^{120}$ Ross P. Buckley, 'Reforming the International Monetary Fund' (2012) 3 Global Policy 104-5.

${ }^{121}$ Wolff (2013-14), 'Failure of the International Monetary Fund' 117-9.

122 Şeffaflığın ve hesap verilebilirliğin güçlendirilmesi; etkili hukuki düzenlemenin arttırılması; finans piyasaların bütünlüğünü teşvik etme; ve uluslararası işbirliğini arttırma alanlarındaki gelişmeler için bkz. Kawai (2010), 'Reform of the International Financial Architecture' 219-28.
} 
artış verilmişti. Daha sonra ikinci ad hoc değişiklik, bütün üye ülkelere büyüklüğüne bakılmaksızın aynı ölçüde (250 olarak belirlenmiş) temel oylarında artış yapma ve Yönetim Kurulunda bulunan Afrika ülkenin temsilini genişletme şeklinde olmuştur. 2008 yılında ise IMF'nin Guvernörler Kurulu sarsılan güvenilirliği ve meşruiyetini yeniden kazanmak amacıyla kota ve temsil oranlarında köklü değişikliler önermiştir ve yeni üyelerin de katılmasıyla artmasına rağmen toplam 46,000 olan temel oy miktarı, Fonun içerisindeki toplam mevcut oy hakkının sadece \%2.1'ini teşkil eder ${ }^{123}$. Bütün bunlar, IMF içerisinde sadece \%5.4 oranında oy hakkının gelişmiş batılı ülkelerden, gelişmekte olan ülkeler ve yükselen piyasa ekonomilerine geçişi sağlanmıştır ${ }^{124}$. Ancak bu artış çok nominal bir değerde olduğu için, özellikle Çin, Brezilya ve Hindistan, aynı zamanda önerilen yeni borç alma düzenlemelerine (NAB) daha ciddi artışlar içeren reformlar yapılmadığı sürece katılmayı reddetmişlerdir. Onun yerine katılımı, yatırım olarak gördükleri IMF notlarını satın almayı tercih etmekle yapmışlardır. 2009 yılında İstanbul'da yapılan IMF ve Dünya Bankası ortak yıllık toplantılarında, gelişmekte olan ülkeler ve yükselen piyasa ekonomilerine güçleri ile daha orantılı bir rol vermek için IMF ve Dünya Bankasının yönetiminde reform yapılması önerisi yenilenmiş ve buna uygun bir reform paketi 2010 yılında G20 zirvesi tarafindan kabul edilerek, IMF'nin kota havuzunun neredeyse iki misli artırılması önerisi diğer bütün üye devletlerin onayına sunulmuştur. Bunun karşılığında Çin, Hindistan, Brezilya ve Rusya satın aldıkları IMF notlarının IMF'nin yeni borç alma düzenlemelerine (NAB) içerisine mali kaynak olarak aktarılmasına müsaade etmişlerdir. 2010 Reformları ile IMF içerisinde en az \%5 oranında oy haklarının ve Dünya Bankası içerisinde ise, \%3 oranında oy haklarının gelişmiş ülkelerden gelişmekte olan ülkelere kaydırılacağı üzerinde anlaşmaya varılmıştır. Hatta aynı yıl her iki kurumun Yönetim Kurulları daha büyük oranda değişiklikleri, üye devletlerin onayı şartına bağlı olarak, kabul etmiş ve her bir devletin dünyanın toplam GDP'si

${ }^{123} 2008$ Reformu esaslı oyları iki misli yapmayı önermiştir. Tenney \& Humphreys (2011), Historical Dictionary 309.

${ }^{124}$ Kota artış1: Kore için $+\% 106$, Singapur için $+\% 63$, Türkiye için $+\% 51$, Çin için + $\%$ 50, Hindistan, Brezilya ve Meksika için ise + \% 40 olmuştur. Bkz. Woods (2010),

'Global Governance after the Financial Crisis' 53. 
içerisindeki yerinin ${ }^{125}$ onun payına düşen oy miktarının hesaplanmasında asli ölçüt olması gerektiğini benimsemiştir ${ }^{126}$.

Bütün devletler ve özellikle ABD yönetimi tarafindan kabul görmesine rağmen, $\mathrm{ABD}$ Kongresi çeşitli vesilelerle anlaşmayı onaylamayı reddetmiştir. ABD bütçesine ciddi bir yük getirmediği halde, Kongredeki muhafazakâr Cumhuriyetçi parti çoğunluğu, mevcut Demokrat başkanlık ve idaresine ve çok taraflı uluslararası ekonomik örgütlere-özellikle IMF'ye- karşı aldıkları olumsuz tavır yüzünden, onaylanmayan reformların hayata geçmesi şimdiye kadar mümkün olmamıştır. ${ }^{127}$ Böylece Bretton Woods kurumlarının reformu ABD tarafindan tıkanmış ve uluslararası para ve finans düzeni bir çıkmazın içerisine sürüklenmiştir. Nitekim 2015 tarihli BRICS Ufa Zirvesi bildirisi, 'IMF 2010 reform paketinin ABD tarafindan onaylanmasının çok uzun bir süreden beri geciktirilmesinden derin bir hayal kırıklığına uğradığını ve bu durumun IMF'nin güvenilirliğine, meşruiyetine ve etkinliğine zarar vermeye devam ettiğini' açık bir ifade ile ortaya koymuştur ${ }^{128}$. BRICS ülkeleri, kendi ekonomileri dünya ekonomisinin beşte birinden fazlası teşkil ettiği halde, bünyesinde sadece toplam $\% 11$ oy hakkına sahip oldukları IMF'nin idari yapısının reform edilmesinin engellenmesini hakkaniyete aykırı bulmaktadırlar ${ }^{129}$. Bunu telafi etmek amacıyla Yeni Kalkınma Bankası ve BRICS Koşullu İhtiyat-Fonu Düzenlemesini kurmuşlardır

\section{ii. Çoğunluk Nisabı}

Yukarıda ifade edildiği gibi, Koşullu İhtiyat-Fonu Düzenlemesi içerisinde karar almada esas olan uzlaşma ilkesi bazı istisnai durumlarda uygulanmaz. Andlaşma, Daimi Komitenin likidite ve ihtiyaten (önleyici) tedbir mahiyetindeki destek veya desteğin yenilenmesi taleplerinin

${ }^{125} \mathrm{Bu}$ tartışmalar için bkz. Lorenzo Fioramonti, 'A Post-GDP World? Rethinking International Politics in the 21st Century' (2015) 7 Global Policy 15-25.

${ }^{126}$ Ayrıntılı eleştirisel bir analiz için bkz. Jakob Vestergaard \& Robert Wade, 'Still in the Woods: Gridlock in the IMF and World Bank Puts Multilateralism at Risk' (2015) 6 Global Policy 2-5.

${ }^{127}$ Robert Wade \& Jakob Vestergaard, 'Why is the IMF at an Impasse, and What Can Be Done about It?' (2015) 6 Global Policy 290-5.

128 Ufa Declaration para.19, VII. BRICS Summit, Ufa, Russia, 9 July 2015, http://en.brics2015.ru/documents/ ; http://www.brics.utoronto.ca/docs/

${ }^{129}$ Raj M. Desai \& James Raymond Vreeland, 'What the new bank of BRICS is all about' The Washington Post 17 July 2014. 
onayını bu istisnanın içerisinde görmüştür ${ }^{130}$. Bu hallerde karar nisabı kreditör devletlerin ağırlıklı oylarının salt çoğunluğu olarak belirlenmiştir. Böylece BRICS, Daimi Komitenin tarafindan işleyişe ilişkin alınan kararlarda esnek bir oylama sistemi benimsemiştir.

Koşullu İhtiyat-Fonu Düzenlemesi içerisinde her bir üye devletin oy hakkı, ona tahsis edilen oyların taşıdığı ağırlığa orantılıdır. Temelde oylar kotaya bağlı bir esas ile tahsis edilir. Şöyle ki, toplam oy hakkının $\% 95$ 'i her bir üye devletin ihtiyat fonu kaynaklarına taahhüt ettiği bireysel mali katkının miktarına göre taraflar arasında dağıtılır. Diğer yandan, toplam oy hakkının \%5'i ise, taraflar arasında eşit bir şekilde paylaştırılır. ${ }^{131} \mathrm{Bu}$ şekli ile oy paylaştırılma sistemi IMF'den farklı değildir. ${ }^{132}$ Nitekim, BRICS 2014 tarihli Fortaleza Bildirisinde IMF'nin kotaya dayanan bir kurum olarak kalması gerektiğini ama yönetim yapısının modernleştirilerek yükselen piyasa ekonomileri ve gelişen ülkelerin dünya ekonomisindeki artan ağıllı̆ını daha iyi yansıtan bir hale gelmesi gerektiğini savunmuştur ${ }^{133}$. Bu yüzden, Koşullu İhtiyat-Fonu Düzenlemesinde çoğunluk kararları bakımından kotaya dayalı bir oy hakk1 görüşünü benimsemesi IMF sistemiyle uyumluluk gösterir.

\section{Mali Kaynak ve Oy Hakk Paritesi}

Koşullu İhtiyat-Fonu Düzenlemesini Kuran Andlaşmanın 3 (e). maddesi göre, basit veya nitelikli oy çoğunluğunun arandığı hallerde Daimi Komite içerisinde her bir taraf devletin oyuna atfedilen ağırlığın hesaplanması şu şekilde belirlenmiştir: i. Eşit oylar ve ii. Ağırlıklı oylar

Eşit oylar, toplam oy hakkının \%5'ini teşkil eder ve taraf devletler arasında eşit olarak dağılır. Buna karşılık ağırlıklı oylar ise, toplam oy hakkının \%95'ini teşkil eder ve taraf devletlerarasında göreceli olarak dağılır. Burada belirleyici ölçüt, her bir taraf devletin fonun mali kaynaklarının oluşturulmasına bireysel olarak taahhüt ettiği katkı payı ile orant1lıdır. Böylece Fon Düzenlemesinin her bir taraf devletin oyuna verilecek hukuki ağırlığın hesaplanması için öngördüğü matematiksel formül, toplam oy hakkının \%5'i $x$ 1/taraf sayısı + toplam oy hakkının $\%$

\footnotetext{
${ }^{130}$ Madde 3 (c) (ii) (iii), Treaty for the Establishment of a BRICS Contingent Reserve Agreement, Fortaleza, 15 July 2015.

${ }^{131}$ A.g.e., Madde 3 (e).

${ }^{132}$ Riesenhuber (2001), The International Monetary Fund, 8-10.

${ }^{133}$ Paragraf 18, Fortaleza Declaration and Action Plan, The Sixth BICS Summit of 2014, Brazil.
} 
95'i $x \mathrm{t} / 100$ milyar ABD dolar1 $=\mathrm{o}$ taraf devletin oyuna $\%$ olarak atfedilecek ağırlıktır. Burada ' $t$ ' taraf devletin fonun mali kaynaklarının oluşturulmasına bireysel olarak taahhüt ettiği katkı payıdır. Bu formülden taraf devletlerin oylarının taşıdığı ağırlık şöyle şekilde hesaplanır:

Çin (41 milyar ABD doları bireysel mali taahhüt ile): \%39.95

Hindistan (18 milyar ABD doları bireysel mali taahhüt ile): \%18.1

Rusya (18 milyar ABD doları bireysel mali taahhüt ile): \%18.1

Brezilya (18 milyar ABD doları bireysel mali taahhüt ile): \%18.1

Güney Afrika (5 milyar ABD doları bireysel mali taahhüt ile): \%5.75

\section{Çin'in Çoğunluk Kararlarındaki Hakimiyeti}

Çin, 41 milyar ABD doları bireysel mali taahhüt ile İhtiyatFonunun toplam kaynaklarının yarıya yakın bir kısmını karşılamaktadır. Dolayısıyla, diğer taraf devletlere kıyasla Çin en çok oy hakkına sahiptir. $\mathrm{Bu}$ ise, ona 3. maddenin c.ii ve c.iii fikralarındaki likidite ve ihtiyaten tedbir mahiyetindeki destek veya desteğin yenilenmesi taleplerinin onay1 hakkındaki kararları önemli ölçüde etkileyebilme gücünü verir. Eğer kredi talebinde bulunan taraf devletin oylamadan muaf tutulacağı düşünülürse, bu durum daha bir ciddiyet arz edebilir. Buna rağmen, oy hakkı dağılımı sisteminin Çin'i fiilen tek başına karara alma durumuna getirmediği görülmektedir. Bu düzenleme içerisinde, Çin'e tahsis edilen oy ağırlığı hiç bir durumda kendi başına salt çoğunluğa yetecek bir seviyeye ulaşmayacak şekilde düzenlenmiş̧ir. Buna örnek verilmek gerekirse, aynı mali katk1 payına sahip Hindistan, Rusya veya Brezilya'dan biri mali destek talebinde bulunursa, Daimi Komitede buna ilişkin bir kararın alınabilmesi için, talepte bulunan devletin dışındaki diğer kreditör taraf devletlerin salt çoğunluğunun onayı gerekmektedir. ${ }^{134} \mathrm{O}$ halde, ancak toplam kalan oy hakkının \%40.95'ine ulaşıldığ taktirde, kreditör taraf devletlerin oy ağırlığında basit çoğunluk sağlanmış olabilir. Yukarıdaki formüle göre hesaplandığında, \%100 oranındaki hak edilen oy sayısı $\% 18.1$ talep eden devletin oy hakk1 $=\% 81.9$ karar nisabına esas teşkil eden oy hakkı olacaktır. Çin'in tek başına sahip olduğu oy hakkı \%39.95 ile sınırlı kalacağı için, bir başka taraf devletin desteğini almadan tek başına olumlu veya olumsuz karar nisabını karşılayamamaktadır. Buna karşı1ık, içerisinde Çin'in bulunmadığı bir çoğunluğun $(\% 18.1+\% 18.1+$ $\% 5.75=\% 41.95)$ karar nisabına ulaştığı görülmektedir. Sonuç olarak

134 Madde 3 (c) (ii), Treaty for the Establishment of a BRICS Contingent Reserve Agreement, Fortaleza, 15 July 2015. 
Daimi Komitede uzlaşının aranmadığı durumlarda, Çin tek başına karar alamadığı gibi bir karar alınabilmesi için Çin'in oylarına da ihtiyaç yoktur. Fakat onun dışındaki bir üçlü koalisyonun oyları gerekir.

Bundan şu şekilde sonuç çıkartmak mümkündür: her bir tarafın oy hakkına atfedilen ağırlık öyle bir şekilde hesaplanmıştır ki, bir mali destek talebi, eğer Çin'in olumlu oyu varsa, en az bir diğer kreditör devletin onayı ile karşılanabilir. Buna karşılık Çin'in karşı oy kullanması halinde, en az kalan diğer üç kreditör taraf devletin ortak olarak mali destek talebini uygun görmesi gerekir. Böylece Çin'in oylamadaki hakim durumu, sadece kendisinin taraf olacağı ikili koalisyonlara imkan tanır; ama kendisine veto hakk1 vermez.

\section{Demokratik Meşruiyet}

BRICS Koşullu İhtiyat-Fonu Düzenlemesini Kuran Andlaşmaya taraf beş devletin hepsinin Guvernörler Konseyi ve Daimi Komitesinde eşit olarak temsil edilmeleri, mali kurumlaşmada demokratik meşruiyetin gözetildiği anlamına gelir. Bunun bir ölçütü olarak taraflar arasında bazı istisnaların dışında bütün kararların uzlaşma esasına dayanarak alınması gösterilebilir. $\mathrm{Bu}$ durumun tek istisnası ise, Daimi Komitede basit çoğunluğa dayanan mali destek taleplerinin onaylanması kararlarıdır. ${ }^{135}$ İhtiyat Fonunun işleyişinde uzlaşma yolu ile demokratik katılımın sağlanması, üzerinde görüş birliği sağlanmış kararların meşruiyetini temin eder. ${ }^{136}$ Ancak bir veya daha çok taraf için önem taşıyan esaslı meselelerin üzerinde ortaya çıkabilecek görüş farklılıklarının giderilemediği hallerde bir karar alınmasını güçleştirebilir ve karar etkinliğinin sadece tali hususlarla sınır kalmasına yol açabilir.

BRICS devletleri arasındaki farklılıklar ve çıkar çatışmaları göz önüne alındığında ${ }^{137}$ grubun heterojen yapısı karşısında bu tür bir düzenlemenin kurumsal başarı için nasıl bir verim sağlayabileceği

\footnotetext{
${ }^{135}$ Yukarlda not.96.

${ }^{136}$ Nitekim Daimi Komitenin bütün meseleler üzerinde görüş birliğine ulaşmak için azami çabayı sarf edeceğini öngörmesi, taraf devletlerarasında demokratik meşruiyeti ön plana çıkardığını gösterir. Madde 3 (d), Treaty for the Establishment of a BRICS Contingent Reserve Agreement, Fortaleza, 15 July 2015.

${ }^{137}$ Pedro Morazȧn et al., The Role of BRICS in the Developing World (Brussels: EU Directorate-General for External Policies, 2012) 27.
} 
tartışma konusudur. ${ }^{138}$ Öte yandan, basit çoğunluğun arandığı kararlar bakımından, Koşullu İhtiyat-Fonu Düzenlemesi içerisinde oy hakkının dağılımı sistemi aslında prensip olarak kotaya dayanan oy ağırlığını benimsemiş olan IMF sisteminden ciddi farklllıklar göstermemektedir ${ }^{139}$. Bununla birlikte IMF içerisinde \%85 nitelikli çoğunluk aranan kararlarda ABD'nin oy dağılımındaki hakim durumu kendisine veto hakkını vermektedir. Bunun aksine, Koşullu İhtiyat-Fonu Düzenlemesi Çin'e tek başına karar alma ve kararı veto hakkını tanımamaktadır. Bu yönden de Düzenlemenin daha yüksek bir demokratik meşruiyet amaçladığı görülmektedir. Nitekim andlaşmada tarafların bu niyeti açıkça Daimi Komitenin bütün meseleler üzerinde uzlaşı sağlanması için gayret sarf edeceğini şeklinde beyan edilmiştir.

\section{Hukuki Statüsü}

BRICS Koşullu İhtiyat-Fonu Düzenlemesini Kuran Andlaşmanın 19. maddesi, ihtiyat fonunun bağımsız uluslararası hukuk kişiliğine sahip olmadığını ve uluslararası andlaşmalara taraf olamayacağı gibi, dava etmek ve dava edilmek kapasitesinin bulunmadığını açıkça hükme bağlamıştır. ${ }^{140}$ İhtiyat fonu uluslararası hukukun tarafı sıfatını taşımadığı için bir uluslararası örgüt değildir. $\mathrm{Bu}$ yönüyle fon, faaliyetlerini destekleyen bir örgüt yapısı kurmadan yapılmış özgün nitelikte çok taraflı finansal düzenlemedir. $\mathrm{Bu}$ durumun, ihtiyat fonu düzenlemesinin uygulamadaki işleyişi üzerinde doğrudan etkileri vardır. Taraf devletler, fon faaliyetlerinin yürütülmesinin her safhasına aktif olarak katılma iradesini ortaya koymuşlardır. Bunun pratik bir sonucu olarak, bir uluslararası örgüt yapısından ziyade BRICS devletlerinin kendisi, mali destek talep eden devletin ihtiyacını karşılamak üzere hareket edecektir. Andlaşmann 5 (c). maddesi, kredi kullanımının 'bağlantısız kısmını' kreditör devletlerle yapılacak anlaşmaya tabi kılmaktadır ${ }^{141}$. Daimi Komitenin taleplere onay verme kararı dahili bir tasarruf olduğuna göre, uluslararası etkiden mahrumdur. Böylece ne Koşullu İhtiyat-Fonu

138 Rolland (2013), 'The BRICS' Contributions' 167-8, Cf. iyimser analizler için bkz. Cooper \& Farooq (2013), 'BRICS' 129; Mikko Huotari \& Thilo Hanemann, 'Emerging Powers and Change in the Global Financial Order' (2014) 5 Global Policy 306-7.

139 IMF'de tepki uyandıran sistemin incelenmesi için bkz. Vestergaard \& Wade (2015), 'Still in the Woods' 4.

${ }^{140}$ Madde 19, Treaty for the Establishment of a BRICS Contingent Reserve Agreement, Fortaleza, 15 July 2015.

${ }^{141}$ A.g.e., Madde 5 (c). 
Düzenlemesinin, ne de Daimi Komitenin uluslararası bir andlaşma akdetme kabiliyeti bulunmadığına göre, BRICS devletleri kendileri mali destek talebinde bulunan devlet ile yapılacak bağlayıcı nitelikteki sözleşmeye bireysel olarak taraf olacaklardır. Bu tarzdaki işleyişin taşıdığı bir tehlike, her ne kadar mali destek talebi Daimi Komite tarafindan uygun görülmüş olsa da bu durum onay kararından sonra bütün kreditör devletlerin sözleşmeyi yapmak hususunda istekli olacağ1 anlamına gelmez. Nitekim, siyasi saikler ile tek taraflı çekimserlik gösteren bir devlet, Koşullu İhtiyat-Fonu Düzenlemesinin faaliyetlerini güçleştirebilir.

Bunun aksine, IMF uluslararası hukuk kişiliğine sahip BM ihtisas kurumudur. $^{142}$ Uluslararası kişiliği, kendisine kurucu andlaşma ile verilmiş olan amaç ve işlevlerini yerine getirebilmesi için, özellikle andlaşma akdetme, mülk edinme ve dava açmak kapasitesini vermektedir $^{143}$. Ayrıca IMF, açıkça feragat etmediği sürece aleyhine açılabilecek her türlü davaya karşı muafiyet hakkına sahiptir. Şüphesiz Koşullu İhtiyat-Fonu Düzenlemesinin uluslararası hukuk kişiliğine sahip olmaması, kurucu andlaşmadaki amaçlarını etkili bir şekilde yerine getirerek, IMF'ye alternatif olmasını güçleştirir.

\section{Mali Kaynaklar ve Elverişliliği}

Koşullu İhtiyat-Fonu Düzenlemesinin başarısı, fonun sağladığı mali desteğin etkinliği ile ölçülür. Çünkü mali destek ihtiyacında olan bir devlet, eğer alacağı yardım miktarı içinde bulunduğu ekonomik krizden kurtulmasına imkân verirse, bu yönde bir talepte bulunmayı düşünür. Bu ise, genel olarak ihtiyat fonunda kullanıma açık mali kaynakların hacmi ve elverişliliğine bağlı bir husustur.

\section{Kaynak Hacmi}

Koşullu İhtiyat-Fonuna taahhüt edilen kaynakların başlangıçta toplam miktarı, 100 milyar ABD doları olarak belirlenmiştir. Bu fondaki kaynaklar, andlaşmaya taraf olan BRICS devletlerinin katkılarıyla oluşur. Her bir taraf devletin mali kaynaklar içerisindeki katkı payı, göreceli olarak onun ekonomik büyüklüğüne bağlanmıştır. Böylece, Çin 41 milyar ABD doları, Brezilya 18 Milyar ABD doları, Rusya 18 Milyar ABD doları, Hindistan 18 Milyar ABD doları ve Güney Afrika 5 Milyar ABD

\footnotetext{
${ }^{142}$ Riesenhuber (2001), The International Monetary Fund, 64-5.

${ }^{143}$ Reparations for injuries suffered in the service of the United Nations, Advisory Opinion ICJ Reports, 1949, p.174, Ian Brownlie, Principles of Public International Law (Seventh edn, Oxford: Oxford University Press, 2008) 676-85.
} 
doları bireysel taahhütte bulunmuştur ${ }^{144}$. Ancak bireysel taahhütlerin derhal fona aktarılması söz konusu değildir. Andlaşma, mali desteğin kullanıma açılmasını onay kararına kadar her bir taraf devletin taahhüt etmiş olduğu katkı payı üzerinde tam mülkiyet haklarını koruyacağını ve parayı zimmetinde tutacağını hükme bağlamıştır. ${ }^{145}$ Kullanıma açılma zamanı, mali destek talebinin onaylanmasını müteakip döviz değişiminin fiilen yapıldığı zamandır. Dolayısıyla, o tarihe kadar olan zaman zarfında fon düzenlemesinin, dolar rezervlerinin gerçekten bir havuzda toplanması yerine, bir nevi 'ödeme senedi modeli' üzerinden yürütüleceği öngörülmüştür. Oysa IMF Statüsü her devletin üyelik katkı payını IMF'deki hesabına peşin olarak yatırmasını öngörür.

IMF'nin 780 milyar ABD doları olan kullanıma elverişli mali kaynakları ile kıyaslandığı takdirde, Koşullu İhtiyat-Fonun kaynak hacminin nispeten sinırlı olduğu görülür. Daha doğru bir etki değerlendirmesi Chiang Mai Initiative Multilaterazation (CMIM) ile yapılabilir. CMIM kaynakları 240 milyar ABD dolarına varan bir çok taraflı döviz değişim düzenlemesidiir ${ }^{146}$. Ancak Chiang Mai Initiative (CMI), 1997-1998 Asya finans krizinden sonra ASEAN+3 grubu tarafından yapılan bir anlaşma ile yerini CMIM'ya bırakmıştır. Kurumsal olarak da Koşullu İhtiyat Fonu Düzenlemesinin CMI/CMIM yapılanmasına benzediği görülür. CMI oluşumunda, başlangıçta daimi bir sekretarya veya yerleşik bir ofise sahip değildi ve sadece temel gözetim kapasitesiyle faaliyet göstermekteydi. İlginç olan CMIM, Koşullu İhtiyat Fonu Düzenlemesinden daha büyük mali kaynak hacmine sahip olduğu halde 2008 küresel finans krizinin Asya'yı etkilemesinde önleyici bir rol oynamamıştır $^{147}$. Oysa BRIC ülkelerinin yabancı döviz rezervlerinin 2014 tarihi itibarıyla yaklaşı 4.4 trilyon (2016 itibarıla tahmini 5.5 trilyon) ABD doları olduğu düşünürse, \%16 oranında bir taahhüt ile Koşullu İhtiyat-Fonundaki havuzu 700 milyar ABD dolarına çıkartabilecek kapasiteye sahiptir $^{148}$.

\footnotetext{
${ }^{144}$ Madde 2 (a), Treaty for the Establishment of a BRICS Contingent Reserve Agreement, Fortaleza, 15 July 2015.

${ }^{145}$ A.g.e., Madde 2 (b).

${ }^{146}$ Cattaneo, Biziwick \& Fryer (2015), 'The BRICS Contingent Reserve Arrangement' 3.

${ }^{147}$ Kawai (2010), 'Reform of the International Financial Architecture' 231-6.

${ }^{148}$ Kavaljit Singh, 'Strengthening Financial Stability? The Promise and Pitfalls of BRICS' 100 Billion Dollar “Contingency Reserve Arrangement” (CRA)' Global Research 5 July
} 


\section{Kredi Sınırı}

Koşullu İhtiyat-Fonu Düzenlemesini Kuran Andlaşmanın 5 (a). maddesi, taraf devletlerin mali kaynaklara önceden tespit edilen azami tahsisat sınırına tabi olarak hak kazanacağını ifade etmektedir ${ }^{149}$. Bu üst sınır, her bir taraf devletin bulunduğu bireysel katkı payı taahhüdünün belirtilen oranlarda katlanmış miktarına eşittir. Bu oranlara göre, Çin'in bireysel katkı payı $x 0.5$ oranında katlanmak üzere azami 20.5 milyar ABD doları kredi tahsisine, Brezilya, Rusya ve Hindistan'1n bireysel katk1 payı $x 1$ oranında olmak üzere azami 18 milyar ABD doları kredi tahsisine ve Güney Afrika'nın bireysel katkı pay1 $x 2$ oranında katlanmak üzere azami 10 milyar ABD doları kredi tahsisine kadar hak kazandığı görülür. Böylece hem likidite ve hem de ihtiyaten tedbirler şeklinde tahsis edilebilecek toplam mali destek miktarı, her bir parti için belirlenen bu azami sınırı geçemeyecektir. $\mathrm{Bu}$ üst sınırlarda ifade edilen kredi miktarlarının küresel bir mali kriz sırasında ne derece yeterli veya etkili olacağı tartışmalıdır ${ }^{150}$.

Ciddi bir ödemeler dengesi açığı yaşayan bir taraf devletin mali destek ihtiyacını karşılamakta yetersiz kalması, Koşullu İhtiyat-Fonu Düzenlemesinin etkili bir seçenek olarak kullanılması olasılığını azaltacağ 1 şüphesizdir. Cattaneo ve diğerleri, kullanıma elverişli kredi kaynaklarının miktarı ve niteliği üzerindeki bu sınırlamaların etkisini 1997 Asya mali krizi sırasında Tayland örneği ile açıklar: Tayland IMF'den 17.2 milyar ABD doları yardım istediği zaman, gayrı safi yurtiçi milli hasılası (GDP) bugün Güney Afrika'nın sahip olduğu gayrı safi yurtiçi milli hasılanın sadece \% 40 oranındaydı. Oysa halihazırda Güney Afrika'nın Koşullu İhtiyat-Fonu Düzenlemesi içerisinde en fazla 10 milyar ABD dolara kadar kredi tahsisine hakk1 vardır ${ }^{151}$.

Ancak belki de İhtiyat Fonu, IMF gibi bir kurtarma amaçlı fonu ikame etmekten çok bir finansal kriz sırasında BRICS devletlerinin sınırlı

2014, http://www.globalresearch.ca/strengthening-financial-stability-the-promise-andpitfalls-of-brics-100-billion-dollar-contingency-reserve-arrangement-cra/5389985

${ }^{149}$ Madde 5 (a), Treaty for the Establishment of a BRICS Contingent Reserve Agreement,

Fortaleza, 15 July 2015.

150 Ben Steil \& Dinah Walker, 'Is the BRICS Contingent Reserve Arrangement a Substitute for the IMF' 6 August 2014, Geo-Graphics, Council on Foreign Relations, http://blogs.cfr.org/geographics/2014/08/06/bricscra/\#

${ }^{151}$ Cattaneo, Biziwick \& Fryer (2015), 'The BRICS Contingent Reserve Arrangement' 6. 
anlamda karşılıklı yardım etme taahhüdü olarak görülebilir. Schöllmann bunu iki olası durum çerçevesinde açıklamaktadır. Ya ödemeler dengesi krizi içerisindeki bir ülkenin merkez bankası, kendi iç piyasasında parasının değerini koruyabilmek için döviz ihtiyacında duyabilir ve diğer taraf ülkelerden yardım ister; ya da hükümet kısa dönemli likidite problemi yaşayabilir ve döviz rezervlerinin daralması karşısında acil ödeme yükümlülüklerini yerine getirebilmek için fondaki tahsisatını kullanır $^{152}$. Düzenleme bu yüzden ihtiyati mahiyettedir.

\section{Onay Koşulları}

Daimi Komite, likidite ve önleyici tedbirler yoluyla destek taleplerini ve bu taleplerin yenilenmesini onaylamaya yetkilidir. Ancak bunu yaparken, Andlaşmanın 5. maddesinde öngörülen bazı koşulların yerine getirilip getirilmediğini incelemek zorundadır. Onay koşullarının ne derece sıkı uygulanacağı, bir anlamda talep edilen mali desteğin azami tahsis sınırına olan oranına bağlı olacaktır. Doğal olarak talep edilen yardım miktarı ne kadar yüksek ise onay koşullarının da o ölçüde sıkı arandığını düşünmek gerekir. Koşullu İhtiyat-Fonu Düzenlemesinde sağlanacak kredi ikili bir ayırıma tabi tutulmuştur: her bir taraf devlet için hesaplanan azami tahsisat sınırının \%30'una tekabül eden 'bağlantısız kısım' ve her bir taraf devlet için hesaplanan azami tahsisat sınırının \%70'ne tekabül eden 'IMF ile bağlantılı kisım'.

\section{a. Bağlantısız Kısım}

Koşullu İhtiyat-Fonu Düzenlemesini Kuran Andlaşma, mali destek talep eden taraf devletin 14. maddede belirtilen koşulları yerine getirmesi halinde kendisi için hesaplanan azami tahsisat sınırının \%30'una tekabül eden kısmının erişimine hak kazanacağını hükme bağlamıştır ${ }^{153}$. Nitekim 14 (b). maddesi resmi koşullar ve güvenceler arasında mali destek talep eden bir tarafin kendisinden istenen bütün belge ve ekonomik ve finansal verileri sunmasını, diğer taraf devletlere ve bölgesel/uluslararası mali kuruluşlara vadesi geçmiş borcu bulunmamasını saymaktadır ${ }^{154}$. Bu

\footnotetext{
${ }^{152}$ Wilhelm Schöllmann, 'The BRICS Bank and Reserve Arrangement: Towards a New Global Financial Framework?' At a Glance, European Parliamentary Research Service, PE542.178, December 2014, 1.

${ }^{153}$ Madde 5 (b), Treaty for the Establishment of a BRICS Contingent Reserve Agreement, Fortaleza, 15 July 2015.

${ }^{154}$ A.g.e., Madde 14 (b) (i-v).
} 
noktada Koşullu İhtiyat-Fonu Düzenlemesi bilinçli olarak IMF'den farklı bir mali yardım politikası izlemeyi tercih etmiştir.

IMF, kendisine üye olan devletlere ödemeler dengesindeki açıkları kapatmak için verdiği yardımları bazı hususi şartlar içeren makroekonomik politikalara tabi tutmaktadır ve/veya devletlerin genel kaynaklardan geçici olarak yararlanabilmesi sağlamak için yeterlilik güvenceleri $\operatorname{aramaktadır}^{155}$. Oysa Koşullu İhtiyat-Fonu Düzenlemesi, verilecek mali yardımların karşılığı bu tür esaslı şartlılık politikasının uygulanmasına ilişkin bir hüküm içermemektedir. Burada öngörülen, IMF tarafından borç alacak ülkenin ekonomik performansını takip edecek bir izleme programına uymaktır ${ }^{156}$. Her ne kadar Andlaşmanın 14 (b) (v). maddesi IMF Statüsünde tanımlandığı şekilde IMF'nin şart koştuğu izleme ve bilgilendirme yükümlülükleriyle ilgili hükümlere uyma zorunluluğuna atıfta bulunuyor olsa da bu hükümlerin hiç biri ek güvencelere veya koşullara bağlı politikaların kabulüne ilişkin herhangi bir hususi şartı içermemektedir. Dolayısıyla Koşullu İhtiyat-Fonu Düzenlemesi, mali destek talep eden taraf devlete, IMF'nin takip ettiği şartlılık kaydı anlamında herhangi bir koşuldan muaf bir mali yardım sağlayabilmektedir. Ancak bu koşulsuz mali yardım sadece destek talep eden taraf devletin hak ettiği azami tahsisat sınırının \%30'una tekabül eden kısmı için geçerli olacaktır. Bu açıdan hesaplandığı zaman, Çin'in koşulsuz mali yardım kaynaklarına olan azami hakkı 6.2 milyar ABD doları ile sinırlı iken, Brezilya, Rusya ve Hindistan'1n azami hakk1 5.4 milyar ABD doları ve Güney Afrika'nın azami hakkı ise 3 milyar ABD doları ile sınırlı olduğu görülür.

\section{b. IMF ile Bağlantılı Kısım}

Koşullu İhtiyat-Fonu Düzenlemesi, taraf devletin kendisi için hesaplanan azami kredi tahsisatının \%70’ne erişimini, IMF ile yapacağı bir "ekonomik gelişmeleri takip anlaşmasına" bağlamıştır. Andlaşmanın 5 (d). maddesi mali destek talep eden devletin kendisine tahsis edilen kredi kaynaklarının tamamına hak kazanabilmesini iki şarta bağlamıştır: (i). 14. maddede sayılan gerekleri yerine getirmelidir. (ii). buna ek olarak, IMF ile arasında kendisinin ekonomik ilerlemesini izleme (on-track) aranjmanının varlığını gösteren bir kanıt sunmalıdır. Bu aranjman, bir yandan IMF'den bu devlet için uygun görülen koşullara bağlı olarak finansal yardımının

\footnotetext{
${ }^{155}$ Lowenfeld (2008), International Economic Law, 644-51.

${ }^{156}$ Schöllmann (2014), 'The BRICS Bank and Reserve Arrangement' 2.
} 
yapılabileceğine dair bir taahhütnameyi içermelidir: öte yandan devletin bu aranjmanın hüküm ve şartlarına uymayı kabul ettiğini göstermelidir ${ }^{157}$. Dolayısı ile eğer bir taraf devlet IMF tarafindan kendisine şart koşulan tedbirleri yerine getirmesini takip eden bir anlaşmaya sahip ise ancak kendisine tahsis edilen kredi kaynaklarının tamamına erişebilecektir. Oysa Koşullu İhtiyat-Fonu Düzenlemesinin kendisi, IMF'nin hangi güvence ve koşulları araması gerektiğine dair hükümler içermez. Bu yüzden de Daimi Komite ihtiyaç halindeki devletin ödemeler dengesindeki açığ 1 nasıl gidereceğine dair makroekonomik politikaları araştırıp, inceleyip önerilerde bulunmaz; bundan ziyade, mali destek talep eden devlet ile IMF arasında gelişmeyi takip anlaşmasının bulunduğunu teyit etmekle yetinir ve buna dayanarak kredi sağlar. Ancak bu durum Koşullu İhtiyatFonu Düzenlemesinin şartlılık politikasını dolayısı ile benimsemediğini göstermez. Nitekim BRICS ülkeleri IMF ile yapılmış bir takip anlaşmasına dayanarak, doğrudan olmasa bile dolayısı ile kendi mali kaynaklarını teminat altına almak için tahsisini belli koşullara bağlamış olduğu görülmektedir. Bunu yaparken, IMF'nin güvence tedbirleri kullanarak, kendi fon düzenlemesi içerisinde onaylanan kaynakları teminat altına almaktadır.

Böylece Koşullu İhtiyat-Fonu Düzenlemesi de facto olarak IMF'nin çok eleştirilen şartlılık politikalarını uygulamaktadır. Buradaki temel problem, BRICS'in makroekonomik izleme ve gözetim altyapısındaki eksikliktir. Taraf ülkelerin ödemeler dengesi durumu hakkında sağliklı, vakitli ve tam bir veri ve bilgi üretecek bir mekanizma henüz daha geliştirilmemiştir. Böyle olunca, borç ihtiyacı içerisinde bulunan bir devletin likidite problemi mi, yoksa borçlarını ödeyebilme gücüyle ilgili bir problemle mi karşı karşıya kaldığını ayırabilmek kapasitesinin bulunduğunu söyleyebilmek zordur ${ }^{158}$. Borç arayan devletin mali disiplinsizliği hem bölgesel hem de uluslararası finansal kriz riski içerdiği için, kreditör devletin bazı şartlara bağlı olarak borç vermesi ve borçlunun bu şartlara uyduğunu izlemesi usulü doğal bir çözümdür. Ancak Eichengreen'in işaret ettiği gibi, bağımsız devletlerin ekonomik egemenliğini koşullara tabi kılmak özellikle BRICS gibi büyük, gururlu ve ciddi farklılıklar arz eden ülkeler bakımından ekonomik olduğu kadar,

\footnotetext{
${ }^{157}$ Madde 5 (d), Treaty for the Establishment of a BRICS Contingent Reserve Agreement, Fortaleza, 15 July 2015

${ }^{158}$ Biziwick, Cattaneo \& Fryer (2015), 'The Rationale' 319.
} 
siyasi olarak da pratik güçlükler içerir ${ }^{159}$. İşte bu yüzden CIMIM'de olduğu gibi, Koşullu İhtiyat-Fonu Düzenlemesi, tahsis edilen krediye erişimi IMF'nin en çok eleştirilen şartll1ık sistemine bağlanmıştır. BRICS devletlerinin makroekonomik performans değerlendirmesini yapabilecek ihtisas ve tecrübeye sahip olmamas1, IMF'nin kurumsal bilgi, beceri ve tecrübesine bağımlı olduğu gerçeğini ortaya koymaktadır.

\section{Tespitler ve Sonuçlar}

BRICS, uluslararası ekonomik düzenin değişen çehresinin bir ürünüdür. $\mathrm{Bu}$ değişim ikili ticari ilişkilerden çok taraflılığa (multilateralism) geçişin bir sonucudur. Küreselleşme ile değişen ekonomik dengeler, mevcut uluslararası para ve finansal idaresinin artık yükselen piyasa ekonomileri ve gelişmekte olan devletlerin ihtiyaçlarına cevap vermekte yetersiz kaldığını göstermiştir. BRICS oluşumu status quo'ya tepkinin bir ifadesidir. Tek kutuplu bir uluslararası düzenden çok kutuplu bir düzene geçme isteğini yansıtır. Bütün ülkelerin ekonomik konum ve menfaatleri oranında küresel mali idare içerisinde adil ve hakça temsil edilmesi için, yeni bir uluslararası finansal mimarı önerilmiştir. BRICS, bu yeni küresel idari yapılanmanın en önemli unsurlarından biri haline gelmeye başlamıştır. Ancak mevcut uluslararası ekonomik düzenin kurucu unsuru olan batılı gelişmiş ülkeler, Bretton Woods sisteminin kurumları olan IMF ve Dünya Bankasının idari yapısı ve işleyişi içerisindeki hakimiyetlerini ve etkilerini korumak amacıyla yeni bir uluslararası mali yapılanmaya direnmektedirler.

Uluslararası örgüt niteliği taşımayan BRICS, başından bu yana gevşek bir birliktelik içerisinde gruplaşma eğilimi göstermiştir. $\mathrm{Bu}$ anlamda işbirliğinin ötesinde, 2015 tarihli Yeni Kalkınma Bankası ve Koşullu İhtiyat-Fonu Düzenlemesi BRICS'in kurumlaşması yönünde atılmış ilk adımdır. $\mathrm{Bu}$ yüzden, iyi tanımlanması ve anlaşılması uluslararası finans hukukuna yapabileceği normatif ve yapısal katkıların değerlendirilmesine imkân sağlayacaktır. Böyle bir değerlendirme iki temel soru etrafinda yapılabilir. Uygulama açısından Koşullu İhtiyat-Fonu Düzenlemesinin uluslararası mali düzene etkisi, bu düzenin belirleyici kurumu olan IMF'ye karşı bir alternatif mi, yoksa onu tamamlayıcı bir

${ }^{159}$ Barry Eichengreen, 'Will the New BRICS Institutions Work?' World Economic Forum, 15 August 2014, http://www.weforum.org/agenda/2014/08/brics-new-developmentbank-contingent-reserve-agreement 
oluşum olarak mı işlev görmesine bağlıdır. İkinci ilgili soru, uluslararası hukukun mali alanda gelişmesine nasıl bir katkıda bulunabileceğine ilişskindir.

İlk soru İhtiyat Fonunun IMF'ye karşı bir alternatif olarak ikame edici işlevi ile mevcut uluslararası finans düzeninin yeniden düzenlenmesini sağlayabilmekte ne kadar etkili olabileceğidir. Yukarıda incelendiği gibi, üç özelliği etkinliği hususunda belirleyici ölçüt olarak görülebilir. Bunlardan ilki kurumsal yapısıdır ve IMF (ve hatta Andean FLAR ve Arab Monetary Fund gibi benzeri bölgesel düzenlemelerden) farklı olarak bir daimi teşkilat merkezinin bulunmaması, kurumsal başkanlık mevkiinin ihdas edilmemiş olması ve asgari bir izleme kapasitesinin oluşturulmamış olması, uluslararası hukuk kişiliğinin eksikliği ile beraber bir uluslararası örgüt kurmak niyeti ile yapılmadığını gösterir. Bu bakımdan kurumsal yapısı ve faaliyetlerinde üye devletlerin hakimiyeti esastır. Bu durum karar alma ve icrasında taraflar devletlerin inisiyatif ve ihtiyarının kurumsal işleyişinin etkili bir şekilde yerine getirilmesinde rol oynayacağını gösterir. BRICS gibi heterojen bir grupta, borç isteyen ile kreditör devletlerin çıkarlarının bazı hallerde örtüşmeyeceği kabul edilirse, uygulamada etkili çözümler sağlanması güçlük arz edebilir. İkinci olarak, bu güçlükleri aşmanın bir yolu, borç arayan devletin bu ihtiyacının kısa dönemde likidite problemi mi, yoksa borçlarını uzun dönemde ödeyebilme yeteneğine (solvency) mi ilişkin olduğunu tespit edebilmek kapasitesidir. Bu ise, borçlu için mali disiplinin sağlanmasına yönelik şartlılık politikasını ve öngörülen şartlara uyulduğunu izlemeyi (surveillance) gerektirir. İşte bu bakımdan, fon düzenlemesinde yer alan ve taraf devlete tahsis edilen yüksek oranda kredinin IMF ile bağlantılı k1lınması en büyük eleştiri kaynağ 1 olmuştur. Gelişmekte olan ve az gelişmiş ülkeleri en çok mağdur eden IMF'nin şartlllık politikaları ve güvence tedbirlerine tepki olarak ortaya çıkan Koşullu İhtiyat Fonu Düzenlemesinin kendisi, sonuçta sağladığı kredilerin $\% 70$ oranını IMF koşulları ve izleme programına tabi kılmıştır. Benzeri bir düzenlemeye sahip CMIM/CMI kurulduğu günden beri Asya finans krizi dahil hiç bir devlet tarafından kullanılmadığı düşünülürse, Koşullu İhtiyat Fonu Düzenlemesinin de benzeri bir çekingenlikle karşılaşması olasıdır. Bu durum üçüncü soruna işaret etmektedir: ihtiyat fonuna kaynak teşkil edecek kredi kaynağının IMF'nin 780 milyar ABD doları değerindeki havuzuna karşı, 100 milyar ABD doları ile sınırlı olmasıdır. 
IMF ile bağlantılı kısmın acil kredi sağlama imkanını daralttığı düşünürse, \%30 oranındaki IMF ile bağlantısız kısmın 3 ila 6 milyar ABD doları arasında olması, bugünkü küresel krizleri önlenmesi ve idaresi için çok yetersiz bir miktar olduğu görülmektedir. Bir başka sorun ise, eğer Koşullu İhtiyat Fonu Düzenlemesinin ihdas edilmesinden maksat, BRICS devletlerinin bir mali kriz sırasında döviz birimi olarak ABD doları ve ABD Merkez Bankasına ( $F e d$ ) bağımlılığını azaltmak ise, fondaki kredi kaynaklarının yine dolar bazından çevrilebilir olarak kabul edilmesinin, IMF'ye karşı bir alternatif olarak yeni bir uluslararası finansal yapılanmayı sağlamaya yönelik olmadığını göstermektedir. Ayrıca İhtiyat Fonu kaynaklarından ödenecek olan kredilerin ABD dolarına çevrilmesi ve geri ödemelerin yine dolar üzerinden talep edilmesi, BRIC devletlerinin ödemeler dengesindeki açıları kapatmakta yeni bir 'uluslararası para' yaratmadığı anlamına gelir. Bu tercih, BRICS'in uluslararası para arzı üzerinde bir kontrol kazanmak niyetinde olmadığını göstermektedir. Bu durumda ödemeler dengesinde açık veren ülkeler, hala bu açığı kapatma hususunda tek başına sorumlu kalırken, ödemeler dengesinde fazlası olan ülkeler bu hususta bir denkleştirme baskısı altında gelmeyeceklerdir. Buna rağmen, BRICS içinde açık veren ülkeler için bunu karşılayacak ek mali kaynak imkanı sunulmuştur. Ancak bu ülkelerin ekonomik hacmi göz önüne alındığında tahsis edilen kaynaklarının yeterliliği fevkalade şüphelidir.

$\mathrm{Bu}$ değerlendirmeler, Koşullu İhtiyat Fonu Düzenlemesinin uygulamada IMF'ye bir alternatif olmaktan çok tamamlayıcı bir oluşum olarak düşünüldüğüne işaret etmektedir. Buna rağmen, BRICS tarafindan böyle bir paralel oluşumun Yeni Kalkınma Bankası ile beraber kurulmuş olmasının, uluslararası para/finans düzeni içerisindeki ilişkileri etkilemesi kaçınılmazdır. Uluslararası hukuk bağlamında, bu etkilerin geniş ve dar anlamda değerlendirilmesi mümkündür. Geniş anlamda, uluslararası hukukun küresel para ve finansal idare bakımından rolü, ticari ilişkiler (Dünya Ticaret Örgütü-WTO) ve yatırım ilişkilerine oranla daha sınırlı olmuştur. Bunun bir nedeni, Bretton Woods sisteminin kökünde ABD ve İngiltere'nin liderliğindeki gelişmiş ülkelerin adeta kapalı bir kulüp modeli içerisinde aralarında yaptıkları çoğu kez gayrı resmi görüşmeler ve işbirliği ile uluslararası mali düzeni şekillendirerek, idare etmiş olmalarından ötürüdür. Evrensel hukuki düzenlemelerin yapıldığı IMF ve Dünya Bankası gibi uluslararası ihtisas örgütlerinin idari yapısı ve karar 
alma mekanizmalarında takip edilen usuller, geleneksel 'bir üye bir oy' esasına dayanan egemen eşitler arasında değil, ama üye devletlerin ekonomik güçleri ile orantılı ağırlı̆̆a sahip katılımına dayanan bir hiyerarşik ilişkiyi içermektedir. Ancak 2008 tarihli küresel mali kriz sonrasında, batılı gelişmiş endüstriyel devletlerin teşkil ettiği G-7 grubunun G-20 grubuna genişletilmesi, BRICS devletleri ile diğer yükselen piyasalar ekonomilerini ve gelişmekte olan devletleri küresel finansal idarenin içerisine getirmiş ve hukuk yapma sürecini etkilemeleri imkanını yaratmıştır. Bunun bir örneği, küresel krizlerin önlenmesi, idaresi ve buna karşı çözümler üretebilmek için kurulan Finansal İstikrar Kuruludur (Financial Stability Board). Böylece ulusal mali krizlerin sınır ötesi etkisi ve sirayetinin önlenmesi ve kontrol altına alınabilmesi için ulusal hukuk düzenlemeleri arasında paralellik ve uyum sağlamak üzere geniş kapsamlı işbirliği ve koordinasyon sağlayan bir küresel kurumsal yapı oluşturulmuştur. Ancak uluslararası hukuk bakımından en genel sorun, ödemeler dengesindeki açığ 1 kapatmak için borç alan devletin tabi kılındığ1 koşullar ve güvence tedbirlerinin o devletin ekonomik egemenliği üzerindeki etkileridir. Koşullu İhtiyat Fonu Düzenlemesinin bu konuda bir yenilik içermediği görülmektedir. BRICS devletlerinin İhtiyat Fonu Düzenlemesine uluslararası hukuk kişiliği tanımaktan imtina etmesi, dar anlamda uluslararası hukukta örgütlere tanınan hak ve yükümlülüklere sahip olmadığını gösterir. $\mathrm{Bu}$ bakımdan uluslararası hukuka yapacağı katkının fevkalade sınırlı olacağı düşünülmelidir.

\section{Kaynakça}

Agarwal, Manmohan (2014), 'The Contingent Reserve Arrangement and the International Monetary System', Analysis, 19 1-5.

Alexander, Kern, Rahul Dhumale and John Eatwell (2006), Global Governance of Financial Systems: The International Regulation of Systemic Risk, (Oxford: Oxford University Press).

Ames, Glen J. (1996), Colbert, Mercantilism and the French Quest for the Asian Trade, (Illinois: Northern Illinois University Press). 
Armijo, Leslie Elliot (2007), 'The BRICs Countries (Brazil, Russia, India, and China) as Analytical Category: Mirage or Insight?', Asian Perspectives, 31 7-42.

Arner, Douglas W. (2008), 'The Developing Discipline of International Financial Law', in Colin B. Picker, Isabella D. Bunn and Douglas W. Arner (ed.), International Economic Law: The State and Future of the Discipline (Oxford: Hart), 245-63.

Bantekas, Ilias (2011), 'New Challenges and Issues in International Finance Law', in Yusuf Aksar (ed.), Implementing International Economic Law: Through Dispute Settlement Mechanisms (Leiden: Martinus Nijhoff),

Biziwick, Mayamiko, Nicolette Cattaneo \& David Fryer (2015), 'The Rationale for and Potential Role of the BRICS Contingent Reserve Arrangement', South African Institute of International Affairs, 22 307-24.

Bordo, Michael D. (1993), 'The Bretton Woods International Monetary System: A Historical Overview', in Eichengreen, Michael D. Burdo \& Berry (ed.), A Retrospective on the Bretton Woods System: Lessons for International Monetary Reform (Chicago: University of Chicago), 398 .

Brown, Bartham (2003), 'IMF Governance, the Asian Financial Crises, and the New International Financial Architecture', in Sienho Yee \& Wang Tieya (ed.), International Law in the Post-Cold War World: Essays in Memory of Li Haopei (London: Routledge), 131-47.

Brownlie, Ian (2008), Principles of Public International Law, (seventh edn., Oxford: Oxford University Press).

Buckley, Ross P (2012), 'Reforming the International Monetary Fund', Global Policy, 3 102-7.

Carmody, Pâdraig (2013), Rise of the BRICS in Africa: The Geopolitics of South-South Relations, (London: Zed).

Cattaneo, Nicollette, Mayamiko Biziwick \& David Fryer (2015), 'The BRICS Contingent Reserve Arangement and Its 
Position in the Emerging Global Financial Architecture', Policy Insight, 10 1-7.

Cooper, Andrew \& Asif B. Farooq (2013), 'BRICS and the Privileging of Informality in Global Governance', Global Polity, 4 $128-33$.

Eatwell, John (1996), International Financial Liberalization: The Impact on World Development, (New York: UNDP Office of Development Studies).

Eichengreen, Barry (1999), Toward a New International Financial Architecture: A Practical Post-Asia Agenda, (Washington, DC: Institute for International Economics).

Eichengreen, Barry (2014), Will the New BRICS Institutions Work?, (World Economic Forum: http://www.weforum.org/agenda/2014/08/brics-newdevelopment-bank-contingent-reserve-agreement).

Fioramonti, Lorenzo (2015), 'A Post-GDP World? Rethinking International Politics in the 21st Century', Global Policy, 7 15-25.

Friedman, Milton (2002), Capitalism and Freedom, (2nd edn., Chicago: Chicago University Press).

Galvão, Marcos (2010), 'Brazil, Russia, India, and China: Brand BRIC Brings Change', The World Today, 66 13-15.

Garraty, John Arthur (1986), The Great Depression: an inquiry into the causes, course, and consequences of the worldwide depression of the nineteen-thirties, as seen by contemporaries and in the light of history, (New York: Harcourt Brace Jovanovich).

Herdegen, Matthias (2013), Principles of International Economic Law, (Oxford: Oxford University Press).

Hobe, Stephan (2010), 'New Trends of International Law in the Era of Globalization', Collected Courses of the Xiamen Academy of International Law, 3 3-79.

Hume, David (1987), 'Of the Balance of Trade', in Miller, Eugene F. (ed.), David Hume's Essays: Moral, Political and Literary (Liberty Fund), Part II:V. 
Huotari, Mikko \& Thilo Hanemann (2014), 'Emerging Powers and Change in the Global Financial Order', Global Policy, 5 298-310.

Ikenberry, G. John (1993), 'The Political Origins of Bretton Woods', in Eichengreen, Michael D. Burdo \& Berry (ed.), A Retrospective on the Bretton Woods System: Lessons for International Monetary Reform (Chicago: University of Chicago), 153-82.

Jensen, Nathan M (2004), 'Crises, Conditions, and Capital: The Effect of International Monetary Fund Agreements on Foreign Direct Investment Flows', Journal of Conflict Resolution, 48 194-210.

Kawai, Masahiro (2010), 'Reform of the International Financial Architecture: An Asian Perspective', The Singapore Economic Review, 55 207-42.

Kettell, Steven (....), 'A Complete Disaster or a Relative Success? Reconsidering Britain's Membership of the ERM, 1990-1992',

http://www2.warwick.ac.uk/fac/soc/pais/people/kettell/ research/erm.pdf,

Kindleberger, Charles P. \& Robert Z. Aliber (2005), Manias, Panics and Crashes: A History of Financial Crises, (New Jersey: John Wiley \& Sons).

Klein, Naomi (2007), The Shock Doctrine: The Rise of Disaster Capitalism, (New York: Metropolitan).

Laïdi, Zaki (2012), 'BRICS: Sovereignty Power and Weakness', International Politics, 49 614-32.

Laeven, Luc \& Fabian Valencia (2008), Systemic Banking Crises: A New Database, (Washington DC: IMF WP/08/224).

Lowenfeld, Andreas F. (2008), International Economic Law, (Second edn., Oxford: Oxford University Press).

Macovei, Mihai (2009), Growth and Economic Crises in Turkey: Leaving behind a Turbulent Past, (Brussels: European Commission Economic Papers 386) 1-36. 
Miller, Eugene F. (1987), David Hume's Essays: Moral, Political and Literary, (Liberty Fund).

Morazȧn, Pedro et al (2012), The Role of BRICS in the Developing World, (Brussels: EU Directorate-General for External Policies).

Nakagawa, Junji (2010), 'Reconstructing Global Monetary/Financial Governance Beyond Bretton Woods System', Japanese Yearbook of International Law, 53 96-121.

Narin, Müslüme \& Dilek Kutluay (2013), 'Değişen Küresel Düzen: BRIC, 3G, N-11 Ülkeleri', Dosya, Ocak/Şubat 31-50.

Negishi, Takashi (1980), History of Economic Theory, (Amsterdam: Elsevier).

O'Neill, Jim (2001), Building Better Global Economic BRICs, (Goldman Sachs).

Oliver, Stuenkel (2013), 'South Africa's BRICS membership: A win-win situation?', African Journal of Political Science and International Relations, 7 310-19.

Posner, Richard A (2011), Economic Analysis of Law, (New York: Aspen).

Quah, Danny (2011), 'The Global Economy's Shifting Centre of Gravity', Global Policy, 2 3-9.

Riesenhuber, Eva (2001), The International Monetary Fund under Constraint: Legitimacy of its Crises Management, (The Hague: Kluwer Law Int'l).

Roberts, Cynthia (2010), 'Challengers or Stakeholders? BRICs and the Liberal World Order, Introduction', Polity, 42 1-13.

Rolland, Sonia E (2013), 'The BRICS' Contributions to the Architecture and Norms of International Economic Law', American Society of International Law Proceedins, 107 164-70.

Sarkar, Rumu (2009), International Development Law: Rule of Law, Human Rights and Global Finance, (Oxford: Oxford University Press).

Schöllman, Wilhelm (2014), 'The BRICS Bank and Reserve Arrangement: Towards a New Global Financial 
Framework?', At a Glance (European Parliamentary Research Service)

Singh, Suresh P. \& Memory Dube (2014), BRICS and the World Order: A Beginner's

Guide,

http://dx.doi.org/10.2139/ssrn.2443652.

Singh, Kavaljit (2000), Taming Global Financial Flows: Challenges and Alternatives in the Era of Financial Globalization: A Citizens Guide, (New York: Zed).

Singh, Kavaljit (2014), 'Strengthening Financial Stability? The Promise and Pitfalls of BRICS' 100 Billion Dollar "Contingency Reserve Arrangement" (CRA)', Global Research, http://www.globalresearch.ca/.

Smith, Adam (2007), An Inquiry into the Nature and Causes of the Wealth of Nations, (Hampshire: Harriman House).

Stiglitz, Joseph E. (2002), Globatization and Its Discontent, (New York: WW Norton).

Tenney, Sarah \& Norman K. Humphreys (2011), Historical Dictionary of the International Monetary Fund, (Lanham: Scarecrow Press).

Vestergaard, Jakob \& Robert Wade (2015), 'Still in the Woods: Gridlock in the IMF and World Bank Puts Multilateralism at Risk', Global Policy, 6 1-12.

Vreeland, Raj M. Desai \& James Raymond (2014), 'What the new bank of BRICS is all about', The Washington Post, 17 July 2014.

Wade, Robert \& Jakob Vestergaard (2015), 'Why is the IMF at an Impasse, and What Can Be Done about It?', Global Policy, 6 290-96.

Walker, Ben Steil \& Dinah (2014), 'Is the BRICS Contingent Reserve Arrangement a Substitute for the IMF?', Geo-Graphics (Council on Foreign Relations: http://blogs.cfr.org/geographics/2014/08/06/bricscra/\#)

Weber, Rolf H (2001), 'Challenges for the New Financial Architecture', Hong Kong Law Journal, 31 241-65. 
Wilson, Dominic \& Roopa Purushothaman (2003), Dreaming with BRICs: The Path to 2050, (Global Economics Paper No.99: Goldman Sachs).

Wolff, Mark J. (2013), 'Failure of the International Monetary Fund \&World Bank to Achieve Integral Development: A Critical Historical Assessment of Bretton Woods Institutions Policies, Structure \& Governance', Syracuse Journal of International Law and Commerce, 41 71-144.

Woods, Ngaire (2010), 'Global Governance after the Financial Crisis: A New Multilateralism or the Last Grasp of the Great Powers?', Global Policy, 1 51-63. 